\title{
1 Variation in shoot tolerance mechanisms not related to ion toxicity in barley
}

2 Joanne Tilbrook ${ }^{1,2}$, Rhiannon K. Schilling ${ }^{1,2}$, Bettina Berger ${ }^{2,3}$, Alexandre F. Garcia ${ }^{1,2,3}$,

3 Christine Trittermann ${ }^{1,2}$, Stewart Coventry ${ }^{2}$, Huwaida Rabie ${ }^{4,6}$, Chris Brien ${ }^{4}$, Martin Nguyen $^{4}$,

4 Mark Tester ${ }^{5}$, Stuart J. Roy ${ }^{1,2, *}$

5

6 Affiliations

7 1. Australian Centre for Plant Functional Genomics, University of Adelaide, PMB1, Glen

8 Osmond, SA 5064, Australia

9 2. School of Agriculture, Food and Wine, University of Adelaide, PMB1, Glen Osmond, SA

10 5064, Australia

11 3. The Plant Accelerator, Australian Plant Phenomics Facility, University of Adelaide, PMB1, 12 Glen Osmond, SA 5064, Australia

13 4. School of Information Technology and Mathematical Services, University of South 14 Australia, Mawson Lakes, SA 5095, Australia

15 5. King Abdullah University of Science and Technology (KAUST), Biological and 16 Environmental Sciences and Engineering (BESE), Thuwal 23955-6900, Saudi Arabia

17 6. Bethlehem University, Rue des Freres \#9, Bethlehem, West Bank, Palestine

$19 *$ Corresponding author

20 Stuart J. Roy, The University of Adelaide, PMB1, Glen Osmond, SA 5064, Australia. 21 stuart.roy@adelaide.edu.au 


\section{Summary}

23 Salinity reduces the grain yield of cereal crops. In this study, non-destructive and destructive 24 phenotyping was used to evaluate 24 predominately Australian barley lines at 0, 150 and 250 $25 \mathrm{mM} \mathrm{NaCl}$. Lines with higher salinity tolerance were better able to maintain their growth rates 26 shortly after salt treatment and exclude $\mathrm{Na}^{+}$from their shoots. This study shows that variation

27 in shoot tolerance mechanisms not related to ion toxicity exists in barley and suggests that 28 breeding new varieties with increased shoot ion independent tolerance is possible. 


\section{Abstract}

30 Soil salinity can severely reduce crop growth and yield. Many studies have investigated salinity 31 tolerance mechanisms in cereals using phenotypes that are relatively easy to measure. The 32 majority of these studies measured the accumulation of shoot $\mathrm{Na}^{+}$and the effect this has on 33 plant growth. However, plant growth is reduced immediately after exposure to $\mathrm{NaCl}$, before $34 \mathrm{Na}^{+}$accumulates to toxic concentrations in the shoot. In this study, non-destructive and 35 destructive measurements are used to evaluate the responses of 24 predominately Australian 36 barley lines at 0,150 and $250 \mathrm{mM} \mathrm{NaCl}$. Considerable variation for shoot tolerance 37 mechanisms not related to ion toxicity (shoot ion independent tolerance) was found, with some 38 lines being able to maintain substantial growth rates under salt stress while others stop growing. 39 Hordeum vulgare L. spp spontaneum accessions and barley landraces predominantly had the 40 best shoot ion independent tolerance, although two commercial cultivars, Fathom and Skiff, 41 also had high tolerance. The tolerance of cv Fathom may be due to a recent introgression from 42 a Hordeum vulgare L. spp spontaneum. This study shows that the most salt tolerant barley lines 43 are those that contain both shoot ion independent tolerance and the ability to exclude $\mathrm{Na}^{+}$from 44 the shoot (and thus maintain high $\mathrm{K}^{+} / \mathrm{Na}^{+}$ratios).

46 Keywords:

47 Hordeum spp., osmotic stress, plant growth, plant phenomics, salt tolerance 
A substantial increase in food production is required to meet the demands of a growing and wealthier world population. Advances in breeding and agronomic practices have achieved, on average, a linear increase in cereal production of 32 million metric tons per year over the past 50 years (Tester and Langridge 2010). However, this current increase in production is insufficient to meet future demands as an increase in 44 million metric tons per year is required between now and 2050 (Tester and Langridge 2010). Achieving this target will be challenging due to increasing fertiliser costs, reduced water availability and quality, variable climates and loss of farmland caused by increasing urbanisation, desertification and salinization (Cassman et al. 2003).

Soil salinity severely reduces crop growth and yield (Munns and Tester 2008; Munns et al. 2012). Within minutes of exposure to salt, cell expansion, leaf expansion, photosynthesis, transpiration and tillering are reduced (Yeo et al. 1991; Passioura and Munns 2000; Fricke and Peters 2002; Colmer et al. 2005; Eynard et al. 2005; Munns and Tester 2008; Rahnama et al. 2011). These effects take place before ions, such as sodium $\left(\mathrm{Na}^{+}\right)$and chloride $\left(\mathrm{Cl}^{-}\right)$accumulate in the shoot and has thus been termed osmotic stress (Munns and Tester 2008) or shoot ion independent stress (Roy et al. 2014). When salts accumulate to toxic concentrations in the shoot, especially in older leaves, a secondary inhibition of growth occurs through damage to plant metabolism and ion imbalances (Wyn Jones et al. 1979; Bhandal et al. 1988; Munns et al. 1995; Blaha et al. 2000; Munns 2002; Munns and Tester 2008; Jacoby et al. 2016). These effects occur weeks to months following salt application and are termed ionic stress or shoot ion dependent stress (Munns et al. 1995; Munns and Tester 2008; Roy et al. 2014).

Plants have evolved numerous mechanisms to detect and respond to the effects of salt stress including a range of signal transduction mechanisms (Kudla et al. 2010; Choi et al. 2014; Schmöckel et al. 2015; Thoday-Kennedy et al. 2015), $\mathrm{Na}^{+}$and $\mathrm{Cl}^{-}$exclusion from the shoot (Munns et al. 2006; Munns and Tester 2008; Teakle and Tyerman 2010), accumulation of $\mathrm{Na}^{+}$ and $\mathrm{Cl}^{-}$in vacuoles (Flowers and Colmer 2008; Munns and Tester 2008; Shabala 2013), synthesis of compatible solutes (Munns and Tester 2008; Shabala 2013), reduced $\mathrm{K}^{+}$efflux from the root (Chen et al. 2005; Chen et al. 2007; Chen et al. 2008) and maintenance of plant 
81 Most studies investigating salinity tolerance mechanisms in cereals use phenotypes that are easily measured: $\mathrm{Na}^{+}$exclusion from the shoot and maintenance of high $\mathrm{K}^{+} / \mathrm{Na}^{+}$ratios by elemental analysis; synthesis of compatible solutes for tissue tolerance by metabolomics analyses, efflux of $\mathrm{K}^{+}$from the root by microelectrode ion flux estimation (MIFE); overall salinity tolerance by measuring plant biomass or, occasionally, grain yield (Zhu et al. 2001; Poustini and Siosemardeh 2004; Colmer et al. 2006; Chen et al. 2008; Cuin et al. 2008; Munns and Tester 2008; Cuin et al. 2009; Widodo et al. 2009; Chen and Murata 2011; James et al. 2012; Munns et al. 2012; Shabala 2013; Adem et al. 2014). However, little is known about the mechanisms contributing to shoot ion independent tolerance, which involves the maintenance of plant growth during salt stress. Plant growth is severely reduced after exposure to salt, before ions accumulate to high concentrations in the shoot and affect the processes in the shoot (Munns et al. 1995; Munns and Tester 2008; Roy et al. 2014). It has been proposed that shoot ion independent tolerance involves long-distance signalling mechanisms, which help maintain plant growth (Roy et al., 2014). However, investigating the maintenance of growth under salt stress has been limited by the lack of techniques which allow non-destructive measurements of plant growth through time.

In recent years non-destructive imaging and analysis has been successfully used to measure plant growth rates under abiotic stresses, using either Red Green Blue (RGB) imaging or infrared thermography (Sirault et al. 2009; Berger et al. 2010; Hairmansis et al. 2014; Honsdorf et al. 2014; Schilling et al. 2014; Neilson et al. 2015; Parent et al. 2015, Al-Tamimi et al. 2016). Growth determined from digital images of shoot area allows for multiple measurements of shoot biomass through time and is an ideal technology to determine the early shoot ion independent effects of salinity on plant growth. The resources and technologies now exist to phenotype many genotypes and identify those with high shoot ion independent and shoot ion dependent tolerance in greenhouse conditions.

Barley (Hordeum vulgare L. ssp vulgare) is one of the more salt tolerant crops, able to grow in higher concentrations of salt than wheat, rice or maize (Maas and Hoffman 1977; Colmer et al. 2005; Tilbrook and Roy 2014). However, growth of barley is still significantly affected by salinity (Colmer et al. 2005). In Europe the highest barley yields are approximately 6-7 t/ha in a favorable year (FAOSTAT 2015), while in Australia yields average 2 t/ha (ABARES 2014; FAOSTAT 2015). One major abiotic stress contributing to this reduction in yield is soil salinity 
114 (Rengasamy and Marchuk 2011). A better understanding of the genetic variation for salinity

115 tolerance mechanisms within barley cultivars is required for future breeding improvement.

117 The work described here details the response of 24 lines of barley to salinity stress. Using non-

118 destructive imaging, shoot growth rates were analysed to determine the shoot ion independent

119 tolerance of each line. A large variation in shoot ion independent tolerance was observed

120 between lines, particularly at concentrations of $250 \mathrm{mM} \mathrm{NaCl}$. The lines that combined shoot

121 ion independent tolerance with other tolerance mechanisms, such as ion exclusion, maintained

122 relatively high shoot biomass over a longer time under $250 \mathrm{mM} \mathrm{NaCl}$, and were typically $H$.

123 spontaneum, landraces or cultivars bred recently using landraces.

Materials and Methods

126

Plant material

Twenty-four commercial and landrace barley lines (Hordeum vulgare L. ssp vulgare and $H$. vulgare L. ssp spontaneum) were selected for this study. These consisted of ten Australian malting varieties, eight Australian feed varieties, two Australian breeding lines (WI4304 (Obsa et al. 2016) and WI4330 (Ismagul et al. 2014), Barley Breeding Program, University of Adelaide), a Chinese feed variety, YU6472 (from China through the Tasmanian Institute of Agriculture and Grains Research \& Development Corporation collaboration), which grows in coastal areas with saline soils (Tajbakhsh et al. 2006)), and three more diverse barley lines known to be tolerant to abiotic stresses: Sahara 3771 (selection from an Algerian landrace), Parent 19 (a Syrian breeding line obtained from the International Center for Agricultural Research in the Dry Areas (ICARDA)) and CPI 71284-48 (H. spontaneum), derived from Commonwealth Plant Introduction \# 71284) (Eglinton et al. 2004).

Experimental design

140 Plants were grown in a greenhouse and an automated phenotyping Smarthouse of the Australian Plant Phenomics Facility, The Plant Accelerator ${ }^{\circledR}$ (TPA) (Waite Campus, University of Adelaide, South Australia, Australia; longitude: $138.639933^{\circ}$, latitude: $-34.971353^{\circ}$ ) between March and April (autumn) of 2012. A split plot experimental design was used, in which 24 varieties were assigned to plots that consisted of three consecutive pots within the same lane in the Smarthouse, with each pot containing a single plant of that line. The three treatment levels $(0,150$ and $250 \mathrm{mM} \mathrm{NaCl})$ were randomized within each plot. The design used to assign the varieties to main plots was a resolved, spatial design with rows and columns. 
148 As the design is resolved, all 72 combinations of the lines and treatments occurred once in a 149 replicate, with each of the eight replicates consisting of six lanes and 12 positions. The design was generated using DiGGer (Coombes 2009), a package for the R statistical computing environment (The R Project for Statistical Computing, 2014).

\section{Plant growth}

154 Evenly sized seeds of each line were selected, placed into $50 \mathrm{~mL}$ polypropylene tubes and 155 imbibed in reverse osmosis (RO) water at room temperature for $2 \mathrm{~h}$. The tubes were drained of 156 water, sealed and placed in the dark at $4^{\circ} \mathrm{C}$ for 3 days. CPI $71284-48$ seeds were similarly 157 imbibed but held for 1 extra day in the dark at $4^{\circ} \mathrm{C}$ to ensure uniform germination with the other lines used in the study. Free draining pots with a diameter of $145 \mathrm{~cm}$ and height of 190 $\mathrm{cm}$ were filled with a soil consisting of $50 \%(\mathrm{v} / \mathrm{v})$ University of California mix, $35 \%(\mathrm{v} / \mathrm{v})$ peat mix and 15\% (v/v) clay loam. Four seeds from each line were sown $2 \mathrm{~cm}$ deep and $2 \mathrm{~cm}$ apart in each replicate pot $(n=7-8)$ and placed in the greenhouse. At sowing, the soil had a gravimetric water content close to $33 \%(\mathrm{w} / \mathrm{w})$. To prevent excessive drying of the soil surface during seed germination, the pots were very lightly sprinkled with RO water each day. At the emergence of the $2^{\text {nd }}$ leaf, the four plants were thinned to one evenly sized plant per pot. The plants were grown under natural light in a temperature-controlled greenhouse with a $22^{\circ} \mathrm{C}$ daytime temperature and $15^{\circ} \mathrm{C}$ at night.

\section{Growth assay under control and salt stress conditions}

When the majority of the seedlings had the $3^{\text {rd }}$ leaf emerging, all pots were transferred into a Smarthouse of TPA and grown under natural light with a daytime temperature of $22^{\circ} \mathrm{C}$ and $15^{\circ} \mathrm{C}$ at night. CPI 71284-48 plants were slower to germinate and were at second leaf emerging when transferred to the Smarthouse. A deep saucer $(160 \mathrm{~cm} \times 160 \mathrm{~cm} \times 90 \mathrm{~cm})$ was placed under each pot and each pot with saucer was placed in an individual cart on the automated conveyor system, where they were imaged, weighed and watered to weight $(25 \% \mathrm{w} / \mathrm{w})$ over the following 21 days (Berger et al. 2012; Brien et al. 2013).

176

At the emergence of the $4^{\text {th }}$ leaf for all plants except the $3^{\text {rd }}$ leaf for CPI 71284-48, salt treatment was applied directly into the saucer in a $200 \mathrm{~mL}$ volume (Berger et al. 2012), to be taken up into the soil over the subsequent $2 \mathrm{~h}$ and $200 \mathrm{~mL}$ of $\mathrm{RO}$ water was used for the $0 \mathrm{mM}$ treatment. Immediately after treatment, the pots contained 0,110 or $180 \mathrm{mM} \mathrm{NaCl}$, with the soil water content at $35 \%(\mathrm{w} / \mathrm{w})$. Pots were then not watered until the soil dried to the target soil water 
182 content of $25 \%(\mathrm{w} / \mathrm{w})$. During this time, the $\mathrm{NaCl}$ concentration in the aqueous phase of the 183 pots increased to 0,150 (moderate salt stress) and 250 (high salt stress) $\mathrm{mM}$, respectively, over a period of 4-6 days after treatment as the soil water content reduced due to evaporation and transpiration. Watering recommenced when the soil water content reached $25 \%(\mathrm{w} / \mathrm{w})$ and was maintained daily to ensure pots were kept at this target water content.

\section{Plant imaging}

Images of plants were taken using a LemnaTec 3D Scanalyzer system (LemnaTec GmbH, Wuerselen, Germany). Three $2056 \times 2454$ pixels RGB images (one top view image and two side view images with a $90^{\circ}$ angle to each other) were taken of each plant daily. Backgroundforeground separation was used to separate the plant from the background and erosion and dilation steps were used to remove noise from the images so that shoot area was not overestimated (Berger et al. 2012; Hairmansis et al. 2014). The sum of plant pixels from three images was calculated and is referred to as the projected shoot area. The projected shoot area has been shown to be linearly correlated to shoot biomass in barley for plant sizes used in the present study (Rajendran et al. 2009; Golzarian et al. 2011; Hairmansis et al. 2014; Honsdorf et al. 2014). Plant health was determined by dividing the number of green pixels in each image by the number of total pixels that made up the image of the plant.

\section{Leaf tissue sampling and analysis}

Leaf blades, which were emerging at the time of treatment, were harvested 17 days after treatment, when they were fully expanded. Fresh weight and dry weight of the leaf tissue was recorded. Dry leaf tissue was digested in $10 \mathrm{~mL}$ of $1 \% \mathrm{HNO}_{3}(\mathrm{v} / \mathrm{v})$ in a HotBlock (Environmental Express, Mount Pleasant, SC, USA) at $85^{\circ} \mathrm{C}$ for $4 \mathrm{~h}$ and leaf $\mathrm{Na}^{+}$and $\mathrm{K}^{+}$ content measured using a flame photometer (Model 420, Sherwood Scientific, Cambridge, UK) (Shavrukov et al. 2010b).

\section{Plant growth curve fitting}

Indicators of plant growth were computed for each day of imaging as follows. A cubic smoothing spline (Shipley and Hunt 1996) was fitted to the projected shoot areas (kpixels) for each plant using the function "smooth.splines", available in the standard R statistical computing environment (R Development Core Team, 2014). The parameter $\mathrm{df}$ of the function was set to 5, as this was judged to produce a fitted curve that followed the general growth trend 
215 of the plants in this study. Absolute growth rates of shoots (AGR kpixels/day) were calculated

216 for each plant for each day on which it was imaged as $\mathrm{AGR}=\mathrm{dA} / \mathrm{dt}$, where $\mathrm{A}$ is the projected 217 shoot area determined from the images. Similarly, relative growth rates (RGR $218 \mathrm{kpixels} /$ day/kpixel) were calculated for each plant for each day on which it was imaged as RGR $219=(1 / \mathrm{A})(\mathrm{dA} / \mathrm{dt})$. The AGR was calculated as the first derivative of the fitted spline using the 220 "predict.smooth.splines" function. The ratios of the relative growth rates were calculated for 221 each triple of consecutive plants for each day on which they were imaged as $R_{\text {GR }}$ salt $/ \mathrm{RGR}_{\text {control }}$ 222 for each salt level. Average relative growth rates between day 0 and day 5 inclusive after salt 223 treatment (a total of 6 days) were calculated for each plant as the geometric mean of their daily 224 RGR values in this interval. The ion independent salt tolerance for this interval was obtained 225 for each triple of consecutive plants as the ratio of the interval RGR for one salt level to the 226 interval RGR for the control. Mixed model analyses were performed using areml-R (Butler $e t$ 227 al. 2010), a package for the R statistical computing environment (The R Project for Statistical 228 Computing, 2014).

\section{Statistical analysis}

231 Data in Supplementary Figure 1 was statistically analysed using a one-way ANOVA in 232 GraphPad PRISM ${ }^{\circledR}$ v7.00 and Tukey's test was used to determine means significantly different 233 at a probability level of $P \leq 0.05$. A Pearson's correlation analysis was performed in GraphPad 234 PRISM $^{\circledR}$ to determine the significance of correlations at a probability level of $P \leq 0.05$.

Results

Salt stressed barley has variable growth responses shortly after salt treatment At the end of the experiment, 17 days after the salt treatment, significant differences in the size of different barley lines was observed in all three treatments $(0,150$ and $250 \mathrm{mM} \mathrm{NaCl})$ (Figure 1). Two of the lines with diverse genetic backgrounds, CPI 71284-48 and Sahara 3771, had a larger shoot biomass (projected shoot area) than the Australian cultivars in all treatments (Figure 1a, b, c). As expected, large reductions in projected shoot area were observed for all lines with increasing $\mathrm{NaCl}$ concentrations (Figure 1). Salinity tolerance was defined as the ability of a line to maintain shoot biomass under salt stress relative to control conditions after 17 days of treatment, calculated as (projected shoot area in salt)/(projected shoot area in control). Lines with salt tolerance ratios closer to 1 are better able to maintain their growth in salt stress conditions to levels similar to that in non-stressed conditions, and are therefore considered to be salt tolerant. Under moderate salt stress (150 $\mathrm{mM} \mathrm{NaCl})$, all lines were able 
to maintain moderate biomass weights, with salt tolerance ratios between 0.3 and 0.7 (Figure 1d). Severe salt stress $(250 \mathrm{mM} \mathrm{NaCl})$ resulted in a much larger separation of the most salt tolerant lines (CPI 71284-48, Sahara 3771, Fathom, Parent 19 and Skiff) from those with poor salt tolerance (Gairdner, Navigator, WI4330 and Yarra) (Figure 1e).

Variation in shoot ion independent stress tolerance exists in barley

Non-destructive imaging of each line for 17 days after salt treatment enabled identification of varietal differences in shoot growth rates (projected shoot area). For all lines, it can be observed that increases in projected shoot area are severely slowed in plants grown in either $150 \mathrm{mM}$ or $250 \mathrm{mM} \mathrm{NaCl}$ (Supplementary Figure 2). However, there are clear differences between different lines. CPI 712484-48 and Sahara 3771 continue to increase projected shoot area after exposure to $250 \mathrm{mM}$, while lines such as Gairdner and Navigator showed little increase in projected shoot area after exposure to $250 \mathrm{mM} \mathrm{NaCl}$ (Supplementary Figure 2).

In the control treatment $(0 \mathrm{mM} \mathrm{NaCl})$, all lines maintained a fairly steady relative growth rate of approximately 0.1 over the 19 days of observations (Figure 2a). After exposure to salt, the RGR of all individuals was either moderately reduced ( $150 \mathrm{mM} \mathrm{NaCl}$ ) (Figure 2b), or severely reduced $(250 \mathrm{mM} \mathrm{NaCl})$ (Figure $2 \mathrm{c}$ ). In both cases, shoot relative growth rates never recovered to the rates observed under non-stressed conditions.

The ability to maintain shoot growth under salt stress at rates similar to those observed in control conditions varied between lines (Figure 3). While most lines were able to maintain similar growth rates to control-grown plants when treated with $150 \mathrm{mM} \mathrm{NaCl}$ (having ratios between 0.8 and 1.0; relative growth rate at $150 \mathrm{mM} /$ relative growth rate at $0 \mathrm{mM}$ ), a large variation in tolerance between the lines was observed at $250 \mathrm{mM} \mathrm{NaCl}$. Three distinct groups of lines with different ratios of relative growth rates over the whole stress period are observed in Figure 3:

- Group 1: Lines that are able to maintain relative growth rates when exposed to $250 \mathrm{mM}$ $\mathrm{NaCl}$ that are close to those measured in plants grown in $0 \mathrm{mM} \mathrm{NaCl}$. Examples include CPI71284-48 and Sahara 3771. These appear to have both high ion independent and dependent tolerance

- Group 2: Lines that have a severe reduction in relative growth rate during the whole period the plants are exposed to $250 \mathrm{mM} \mathrm{NaCl}$. Examples include Gairdner, Clipper and Keel. These appear to have low ion-independent tolerance and may or may not have 
290

good ion tolerance. This cannot easily be resolved, as growth has been so significantly reduced by the rapid, ion-independent effects.

- Group 3: Lines that exhibit a severe reduction in relative growth rates, but then recover slightly approximately 10 days after addition of $250 \mathrm{mM} \mathrm{NaCl}$, although with still much lower growth rates than seen in $0 \mathrm{mM} \mathrm{NaCl}$. Examples include Baudin, Mundah and Barque 73. These lines may require a period of adjustment before activating both ionindependent and dependent tolerance

Shoot ion independent stress reduces the growth rate of barley immediately after the addition of $\mathrm{NaCl}$. Over time, $\mathrm{Na}^{+}$and $\mathrm{Cl}^{-}$accumulate in leaf tissue resulting in shoot ion dependent stress and further growth reduction. Therefore to assess the shoot ion independent stress tolerance on its own, before the compounding factors of ion accumulation, the difference between salt and control relative growth rates over the first 5 days after exposure to salt was used to calculate an average shoot ion independent tolerance for each line (Figure 4). Under $150 \mathrm{mM} \mathrm{NaCl}$ stress, most of the barley lines had good shoot ion independent tolerance ( 0.8 to 1.0), with Fathom and CM72 being able to maintain relative growth rates at $150 \mathrm{mM} \mathrm{NaCl}$ similar to that when grown in $0 \mathrm{mM} \mathrm{NaCl}$ (Figure 4a).

For plants grown in $250 \mathrm{mM} \mathrm{NaCl}$, a large variation in the shoot ion independent tolerance was observed (Figure 4b). Fathom and Parent 19 were the best performing lines, with similar relative growth rates over the first 5 days after exposure to $250 \mathrm{mM} \mathrm{NaCl}$ compared to $0 \mathrm{mM}$ $\mathrm{NaCl}$ (Figure 4b). WI4304 and Navigator had the lowest shoot ion independent tolerance (0.376 and 0.388, respectively) (Figure 4b). The remaining lines, from Clipper to CPI 7128448 exhibited a range of shoot ion independent tolerance from 0.46 to 0.82 (Figure 4b). At 150 $\mathrm{mM}$, a slight positive relationship between shoot ion independent tolerance (maintenance of growth over the first 5 days) and overall plant salinity tolerance (as determined at final imaging point) was observed (Figure 4c). At a high salinity treatment of $250 \mathrm{mM}$, there is a clear correlation between shoot ion independent tolerance and overall plant salinity tolerance (Figure $4 d)$.

\section{$\mathrm{Na}^{+}$exclusion from barley leaves only linked to salinity tolerance under high salinity stress} Under non-stressed and $150 \mathrm{mM} \mathrm{NaCl}$ conditions, there was little variation in leaf $\left[\mathrm{Na}^{+}\right]$and $\left[\mathrm{K}^{+}\right]$between lines (Figure 5), no relationship between leaf $\left[\mathrm{Na}^{+}\right]$and final projected shoot area 17 days after treatment and a negative relationship between leaf $\left[\mathrm{Na}^{+}\right]$and salinity tolerance 
317 (Figure 6a, b). At 250 mM NaCl, several lines (CPI 71284-48, Sahara 3771, Mundah, Fathom,

318 Skiff and Parent 19) accumulated low $\left(<250 \mathrm{mM} \mathrm{Na}^{+}\right)$concentrations of leaf $\left[\mathrm{Na}^{+}\right]$, similar to 319 the concentrations they accumulated in $150 \mathrm{mM} \mathrm{NaCl}$ (Figure $5 \mathrm{c}$, e). While many lines were 320 able to maintain leaf $\left[\mathrm{K}^{+}\right]$levels similar to those in $0 \mathrm{mM} \mathrm{NaCl}$ (Figure $5 \mathrm{~b}, \mathrm{f}$ ), others, such as 321 Keel, Hindmarsh, WI4304 and Clipper exhibited a doubling in leaf $\mathrm{K}^{+}$concentration and lower 322 leaf water contents (Table 1). Many lines, however, accumulated very high $\left[\mathrm{Na}^{+}\right](>850 \mathrm{mM}$ $323 \mathrm{NaCl}$ ) in their leaves; these included Navigator, WI4330, WI4304, Hindmarsh and Gairdner 324 (Figure 5e). In the $250 \mathrm{mM} \mathrm{NaCl}$ treatment there was a clear negative relationship between leaf $325\left[\mathrm{Na}^{+}\right]$and both final projected shoot area (plant biomass) and salinity tolerance (Figure 6c, d). 326 When grown in $250 \mathrm{mM} \mathrm{NaCl}$ a large variation in leaf health, the proportion of green shoot to 327 total leaf pixel area, was observed between cultivars (Figure 6e) with lines that accumulated 328 high leaf $\left[\mathrm{Na}^{+}\right]$exhibiting classic symptoms of salinity stress, including high levels of leaf senescence and thus reduced proportions of healthy green shoot area (Figure 6f).

\section{Salinity tolerance in barley is a combination of many traits}

332 When barley lines were ranked on their salinity tolerance at $250 \mathrm{mM} \mathrm{NaCl}$ (Table 1) and 150 $333 \mathrm{mM} \mathrm{NaCl}$ (Supplementary Table 1) a number of observations can be made. In $250 \mathrm{mM} \mathrm{NaCl}$, 334 the barley lines with the highest salt tolerance are also those with the highest shoot ion 335 independent tolerance, the lowest leaf $\mathrm{Na}^{+}$accumulation, the highest $\mathrm{K}^{+} / \mathrm{Na}^{+}$ratios and the highest leaf health (Table 1). Consistently, those lines with the lowest salt tolerance also had the lowest shoot ion independent tolerance, highest leaf $\mathrm{Na}^{+}$accumulation, were unable to maintain leaf $\mathrm{K}^{+} / \mathrm{Na}^{+}$ratios and had the lowest leaf health (or greenness) (Table 1). When ranked by salt tolerance, shoot ion independent tolerance or $\mathrm{Na}^{+}$exclusion, malting barley cultivars tended to have the poorest tolerance, while feed barley had moderate tolerance (Table 1; Supplementary Figure 1). Diverse genotypes had the best salt tolerance, with two exceptions being the malting barley Skiff and the feed barley Fathom which also had high salt tolerance. At $150 \mathrm{mM} \mathrm{NaCl}$, plants which had good shoot ion independent tolerance and $\mathrm{Na}^{+}$exclusion tended to also have the greatest salinity tolerance, however, this was not as apparent as the

\section{Discussion}

348 In this study, non-destructive and destructive measurements are used to evaluate the responses 349 of 24 barley lines under different salt concentrations. Considerable variation was shown to exist 350 in barley for: 
- Shoot ion independent tolerance, the response of plants that occurs before salt has had a chance to both accumulate in the shoot and affect processes in the shoot.

- Salinity tolerance, as quantified by projected shoot area after 17 days in salinity relative to the projected shoot area of plants grown in optimal conditions; and

- $\mathrm{Na}^{+}$and $\mathrm{K}^{+}$accumulation in leaf blades

It was found that the most salt tolerant barley lines are those that possess multiple salt tolerant mechanisms. Wilder accessions of barley had the greatest salt tolerance and had both high $\mathrm{Na}^{+}$ exclusion and shoot ion independent tolerance. Interestingly, Skiff (a malting variety now grown as feed) and Fathom (a feed variety) had disproportionately higher salt tolerance compared to other cultivars of their type.

\section{Variation for shoot ion independent tolerance in barley}

An immediate reduction in plant growth can be observed for every line after the addition of $\mathrm{NaCl}$ (Figure 3 and Supplementary Figure 2), as determined by a reduction in the relative growth rates (Figure 3) of the plants and their shoot ion independent tolerance (Figure 4). Lines have been identified that are better able to maintain their growth when exposed to salt, such as Sahara 3771, Fathom, CPI-71284-48 and Parent 19 (Figures 3 and 4). While their growth rates slowed upon the application of salt, these lines were still able to expand their leaves and maintain shoot growth. This study also found that the growth of most lines was reduced under high salt for a prolonged period - the rapid reduction in growth was not reversed (Figure 3). Lines such as YU6472, Navigator, Commander and Keel, stopped growing when exposed to $250 \mathrm{mM} \mathrm{NaCl}$. It is hypothesised that these lines may have closed their stomata, thereby limiting photosynthesis and consequently leaf expansion and tillering (Munns and Tester 2008). In addition to identifying lines that either maintained growth after salt stress or had their growth inhibited by salt, this study also identified a small number of lines that had an immediate reduction in growth rate but then showed growth rate recovery approximately 10 days after exposure to salt (Figure 3). This may be an adaptive response to the salinity treatment, where plant growth is delayed while necessary salt tolerance mechanisms are activated. Alternatively, it may be an escape mechanism, where plants temporarily suspend growth on exposure to high salt levels, thereby temporarily reducing damage, but then resume growth despite salt levels remaining high.

\section{Mechanisms behind growth maintenance under salt still need to be elucidated}


384 Mechanisms for shoot growth maintenance shortly after exposure to salinity before ions 385 accumulate to high concentrations in shoot tissue (shoot ion independent tolerance) are as yet unknown (Roy et al. 2014). It seems likely to involve rapid long distance signalling components which occur immediately after exposure to salt, along with stomatal closure and synthesis of compatible solutes (Fricke et al. 2004; James et al. 2008; Sirault et al. 2009; Kudla et al. 2010; Mittler et al. 2011; Roy et al. 2014). Hydraulic signalling as well as non-hydraulic processes (such as transient calcium, reactive oxygen species and hormone fluxes, lasting minutes to hours), have all been implicated in the signalling of salt stress (Munns et al. 2000; Kudla et al. 2010; Mittler et al. 2011; Choi et al. 2014; Huber and Bauerle 2016). However, as can be observed from Figures 3 and 4 and Supplementary Figure 2, the reduction in growth rates of many lines exposed to salinity stress is maintained over a period of days, for much longer than the transient signals have been observed. It is thus likely that longer lasting responses (and possibly also signals) exist, in addition to the transient signals, which are responsible for maintaining slowed growth rates under salinity. Now that tolerant lines have been identified, the mechanisms behind their ability to maintain growth can be investigated. Forward genetic approaches, such as bi-parental quantitative trait locus (QTL) mapping or genome wide association mapping, are required to identify genetic loci linked to maintenance of growth under salt.

Performance in unstressed conditions does not predict good shoot ion independent tolerance

404 No relationship between the shoot ion independent tolerance and the initial projected shoot area (prior to salt treatment) or their relative growth rates under $0 \mathrm{mM} \mathrm{NaCl}$ treatment was observed for the barley lines grown in this study (Supplementary Figure 3). This suggests that the performance of barley lines under non-stressed conditions does not predict their performance under salt - e.g. there is no evidence that barley lines with the highest ion independent tolerance are the slowest growing. This is promising for plant breeders, as it will be possible to introduce mechanisms to maintain growth under salinity without adversely affecting the growth rate of plants in non-stressed environments. The finding that Fathom, a high yielding cultivar in the field (Paynter et al. 2014; Matthews et al. 2015; Victoria 2015; Wheeler 2015), has a high shoot ion independent tolerance suggests it is possible to introgress salinity tolerance traits into barley without detrimental effects on grain yield.

\section{Multiple tolerance mechanisms are necessary for overall salt tolerance}


417 In the quest to increase crop salinity tolerance, research is often focused on improving one mechanism of tolerance, be it exclusion of $\mathrm{Na}^{+}$from the shoot, maintenance of high $\mathrm{K}^{+} / \mathrm{Na}^{+}$ ratios in the shoot, tolerance of high $\mathrm{Na}^{+}$in the shoot, synthesis of compatible solutes or reducing efflux of $\mathrm{K}^{+}$from the root. While these traits are individually important, and manipulation of them in isolation has improved yield in the field (James et al. 2012), it is likely that a combination of these tolerance mechanisms will have the greatest impact on improving crop performance in a saline field. The introgression of a gene important in regulating shoot $\mathrm{Na}^{+}$exclusion, TmHKT1;5-A, from T. monococcum into the durum wheat (T. durum cv Tamaroi), resulted in improved yield in the field, but only in highly saline soils (James et al. 2012; Munns et al. 2012). The yield of the TmHKT1;5-A Tamaroi was similar to the Tamaroi parent under low and moderate salinity, suggesting that other traits, such as shoot ion independent tolerance, need to be introgressed into those lines to improve yield in mild and moderate saline environments.

Of the 24 barley lines in this study, it was those with both shoot ion dependent and shoot ion independent tolerance that were the most salt tolerant (Table 1). There was no evidence that a single tolerance mechanism dramatically improved salinity tolerance alone, similar to observations in wheat (Rajendran et al. 2009). The focus for pre-breeders and breeders in the future should be on the identification of the best traits and mechanisms to pyramid together in elite cultivars to obtain the most effective increases in salt tolerance that benefits crops growing under variable levels of salinity.

\section{Introduction of wild barley tolerance mechanisms into commercial varieties is possible}

The barley lines with the highest overall salinity tolerance were generally wilder accessions (Table 1), which are lower yielding than commercial cultivars (in terms of yield per plant) but are better adapted to more extreme environments. CPI 71284-48 is a $H$. vulgare spp spontaneum accession (Shavrukov et al. 2010a), which is found in environments with extreme stresses, such as high temperatures, drought and soil salinity; Sahara 3771 is a line derived from an Algerian landrace (Sutton et al. 2007) while Parent 19 is an ICARDA breeding line from Syria. Of the 24 barley lines used in this study, the majority of Australian cultivars bred for malting had lower salinity tolerance than those bred for feed (Table 1). The reason that these malting barleys generally have lower salinity tolerance than the feed barleys remains unclear. Feed barley often share similar pedigrees and are selected under the same field conditions as malting barley cultivars. It is unlikely that the lower salt tolerance in malting 
451 barley is due to salinity tolerance mechanisms being incompatible with mechanisms for

452 producing grain with high malting quality, as the malting cultivar Skiff has the best salinity

453 tolerance of all cultivars measured (Table 1).

455 Interestingly, Skiff (malting barley) and Fathom (feed barley) have overall very high salinity 456 tolerance, disproportionately so to others of their type. Fathom has CPI-71284-48 in its 457 pedigree, while Skiff has an Algerian H. vulgare landrace, CPI-18197-48, in its background. It 458 is likely that introgression of DNA from these two wilder accessions is responsible for the 459 observed salinity tolerance. Several mapping populations between CPI-71284-48 and 460 Australian cultivars already exist. While some of these have already been studied to identify 461 traits linked to $\mathrm{Na}^{+}$exclusion (Schilling et al., in preparation), the opportunity now exists to 462 use these existing mapping populations to identify alleles and genes for shoot ion independent 463 tolerance.

\section{Acknowledgements}

466 The authors would like to acknowledge funding from the Grains Research and Development 467 Corporation, Australia (UA00118 and UA00145) and the Adelaide Barley Breeders 468 (University of Adelaide) for advice and plant material. The Plant Accelerator ${ }^{\circledR}$, Australian Plant 469 Phenomics Facility, is funded by the National Collaborative Research Infrastructure Strategy 470 (NCRIS) of the Commonwealth of Australia. Accession YU6472 was supplied through a China 471 Tasmanian Institute of Agriculture and Grains Research and Development Corporation 472 collaboration and Parent 19 was sourced from the International Center for Agricultural 473 Research in the Dry Areas (ICARDA), Lebanon.

\section{Conflict of Interest}

476 The authors declare no conflicts of interest. 


\section{References}

ABARES (2014) 'Agricultural commodity statistics 2014.' (Australian Government: Canberra) Adem, G, Roy, S, Zhou, M, Bowman, J, Shabala, S (2014) Evaluating contribution of ionic, osmotic and oxidative stress components towards salinity tolerance in barley. BMC Plant Biology 14, 113.

Al-Tamimi, N, Brien, C, Oakey, H, Berger, B, Saade, S, Shwen Ho, Y, Schmöckel, SM, Tester, M, Negrão, S (2016) Salinity tolerance loci revealed in rice using high-throughput noninvasive phenotyping. Nature Communications 7: 13342

Berger, B, de Regt, B, Tester, M (2012) High-throughput phenotyping of plant shoots. In 'HighThroughput Phenotyping in Plants.' (Ed. J Normanly.) pp. 9 - 20. (Humana Press: New York)

Berger, B, Parent, B, Tester, M (2010) High-throughput shoot imaging to study drought responses. Journal of Experimental Botany 61, 3519-3528.

Bhandal, IS, Malik, CP, Bourne, GH, Jeon, KW, Friedlander, M (1988) Potassium estimation, uptake, and its role in the physiology and metabolism of flowering plants. International Review of Cytology 110, 205-254.

Blaha, G, Stelzl, U, Spahn, CMT, Agrawal, RK, Frank, J, Nierhaus, KH (2000) Preparation of functional ribosomal complexes and effect of buffer conditions on tRNA positions observed by cryoelectron microscopy. In 'Methods in Enzymology.' Vol. 317 pp. 292306. (Academic Press:

Brien, C, Berger, B, Rabie, H, Tester, M (2013) Accounting for variation in designing greenhouse experiments with special reference to greenhouses containing plants on conveyor systems. Plant Methods 9, 5.

Butler, DG, Cullis, BR, Gilmour, AR, Gogel, BJ (2010) 'Analysis of Mixed Models for S language environments: ASReml-R reference manual.' (DPI Publications: Brisbane)

Cassman, KG, Dobermann, A, Walters, DT, Yang, H (2003) Meeting cereal demand while protecting natural resources and improving environmental quality. Annual Review of Environment and Resources 28, 315-358.

Chen, THH, Murata, N (2011) Glycinebetaine protects plants against abiotic stress: mechanisms and biotechnological applications. Plant Cell \& Environment 34, 1-20.

Chen, Z, Newman, I, Zhou, M, Mendham, N, Zhang, G, Shabala, S (2005) Screening plants for salt tolerance by measuring $\mathrm{K}^{+}$flux: a case study for barley. Plant Cell \& Environment 28, 1230 - 1246.

Chen, Z, Pottosin, I, Cuin, T, Fuglsang, A, Tester, M, Jha, D, Zepeda-Jazo, I, Zhou, M, Palmgren, M, Newman, I, Shabala, S (2007) Root plasma membrane transporters controlling $\mathrm{K}^{+} / \mathrm{Na}^{+}$homeostasis in salt-stressed barley. Plant Physiology 145, 1714 1725.

Chen, Z, Shabala, S, Mendham, N, Newman, I, Zhang, G, Zhou, M (2008) Combining Ability of Salinity Tolerance on the Basis of NaCl-Induced K Flux from Roots of Barley. Crop Science 48, 1382-1388.

Choi, W-G, Toyota, M, Kim, S-H, Hilleary, R, Gilroy, S (2014) Salt stress-induced $\mathrm{Ca}^{2+}$ waves are associated with rapid, long-distance root-to-shoot signaling in plants. Proceedings of the National Academy of Sciences 111, 6497-6502.

Colmer, TD, Flowers, TJ, Munns, R (2006) Use of wild relatives to improve salt tolerance in wheat. Journal of Experimental Botany 57, 1059-1078.

Colmer, TD, Munns, R, Flowers, TJ (2005) Improving salt tolerance of wheat and barley: future prospects. Australian Journal of Experimental Agriculture 45, 1425-1443.

Coombes, NE (2009) 'DiGGer design search tool in R.' Available at http://www.austatgen.org/files/software/downloads/ 
Cuin, T, Tian, Y, Betts, S, Chalmandrier, R, Shabala, S (2009) Ionic relations and osmotic adjustment in durum and bread wheat under saline conditions. Functional Plant Biology 36, 1110 - 1119.

Cuin, TA, Betts, SA, Chalmandrier, R, Shabala, S (2008) A root's ability to retain $\mathrm{K}^{+}$correlates with salt tolerance in wheat. Journal of Experimental Botany 59, 2697-2706.

Eglinton JK, Coventry SJ, Mather DE, Kretschmer J, McMichael GL, Chalmers KJ (2004) Advanced backcross QTL analysis in barley. In: Proceedings of the 9th International Barley Genetics Symposium, Brno, Czech Republic, p 65

Eynard, A, Lal, R, Wiebe, K (2005) Crop response in salt affected soils. Journal of Sustainable Agriculture 27, 5-50.

FAOSTAT (2015) 'Food and agriculture organisation of the United Nations Statistics Division.' Available at http://faostat3.fao.org/home/E

Flowers, TJ, Colmer, TD (2008) Salinity tolerance in halophytes. New Phytologist 179, 945 963.

Fricke, W, Akhiyarova, G, Veselov, D, Kudoyarova, G (2004) Rapid and tissue-specific changes in ABA and in growth rate in response to salinity in barley leaves. Journal of Experimental Botany 55, 1115-1123.

Fricke, W, Peters, WS (2002) The biophysics of leaf growth in salt-stressed barley. A study at the cell level. Plant Physiology 129, 374-388.

Golzarian, MR, Frick, RA, Rajendran, K, Berger, B, Roy, SJ, Tester, M, Lun, DS (2011) Accurate inference of cereal plant biomass using information extracted from highthroughput plant images, Plant Methods 7:2

Hairmansis, A, Berger, B, Tester, M, Roy, S (2014) Image-based phenotyping for nondestructive screening of different salinity tolerance traits in rice. Rice 7, 16.

Honsdorf, N, March, TJ, Berger, B, Tester, M, Pillen, K (2014) High-throughput phenotyping to detect drought tolerance QTL in wild barley introgression lines. PLOS One 9, e97047.

Huber, AE, Bauerle, TL (2016) Long-distance plant signaling pathways in response to multiple stressors: the gap in knowledge. Journal of Experimental Botany 67, 2063-2079.

Ismagul, A, Mazonka, I, Callegari, C, Eliby, S (2014) Agrobacterium-mediated transformation of barley (Hordeum vulgare L.). In 'Crop Breeding: Methods and Protocols.' (Eds D Fleury, R Whitford.) pp. 203-211. (Springer New York: New York, NY)

Jacoby, RP, Che-Othman, MH, Millar, AH, Taylor, NL (2016) Analysis of the sodium chloride-dependent respiratory kinetics of wheat mitochondria reveals differential effects on phosphorylating and non-phosphorylating electron transport pathways. Plant Cell \& Environment 39, 823-833.

James, R, Sv, C, Condon, A, Zawrt, A, Munns, R (2008) Genetic variation in tolerance to the osmotic stress component of salinity stress in durum wheat. Functional Plant Biology 35, $111-123$.

James, RA, Blake, C, Zwart, AB, Hare, RA, Rathjen, AJ, Munns, R (2012) Impact of ancestral wheat sodium exclusion genes Naxl and Nax2 on grain yield of durum wheat on saline soils. Functional Plant Biology 39, 609-618.

Kudla, J, Batistic, O, Hashimoto, K (2010) Calcium signals: The lead currency of plant information processing. The Plant Cell 22, 541-563.

Maas, EV, Hoffman, GJ (1977) Crop salt tolerance - current assessment. Journal of Irrigation and Drainage 103, 115-134.

Matthews, P, D., M, L., J (2015) 'Winter crop variety sowing guide 2015.' (NSW Department of Primary Industries: New South Wales, Australia) 
Mittler, R, Vanderauwera, S, Suzuki, N, Miller, G, Tognetti, VB, Vandepoele, K, Gollery, M, Shulaev, V, Van Breusegem, F (2011) ROS signaling: the new wave? Trends in Plant Science 16, 300-309.

Munns, R (2002) Comparative physiology of salt and water stress. Plant Cell \& Environment 25, 239-250.

Munns, R, James, RA, Lauchli, A (2006) Approaches to increasing the salt tolerance of wheat and other cereals. Journal of Experimental Botany 57, 1025-1043.

Munns, R, James, RA, Xu, B, Athman, A, Conn, SJ, Jordans, C, Byrt, CS, Hare, RA, Tyerman, SD, Tester, M, Plett, D, Gilliham, M (2012) Wheat grain yield on saline soils is improved by an ancestral $\mathrm{Na}^{+}$transporter gene. Nature Biotechnology 30, 360-364.

Munns, R, Passioura, JB, Guo, J, Chazen, O, Cramer, GR (2000) Water relations and leaf expansion: importance of time scale. Journal of Experimental Botany 51, 1495-1504.

Munns, R, Schachtman, DP, Condon, AG (1995) The significance of a two-phase growth response to salinity in wheat and barley. Australian Journal of Plant Physiology 22, 561-569.

Munns, R, Tester, M (2008) Mechanisms of salinity tolerance. Annual Review of Plant Biology 59, 651-681.

Neilson, EH, Edwards, AM, Blomstedt, CK, Berger, B, Møller, BL, Gleadow, RM (2015) Utilization of a high-throughput shoot imaging system to examine the dynamic phenotypic responses of a $\mathrm{C} 4$ cereal crop plant to nitrogen and water deficiency over time. Journal of Experimental Botany 66, 1817-1832.

Obsa, BT, Eglinton, J, Coventry, S, March, T, Langridge, P, Fleury, D (2016) Genetic analysis of developmental and adaptive traits in three doubled haploid populations of barley (Hordeum vulgare L.). Theoretical and Applied Genetics 129, 1139-1151.

Parent, B, Shahinnia, F, Maphosa, L, Berger, B, Rabie, H, Chalmers, K, Kovalchuk, A, Langridge, P, Fleury, D (2015) Combining field performance with controlled environment plant imaging to identify the genetic control of growth and transpiration underlying yield response to water-deficit stress in wheat. Journal of Experimental Botany 66, 5481 - 5492.

Passioura, JB, Munns, R (2000) Rapid environmental changes that affect leaf water status induce transient surges or pauses in leaf expansion rate. Australian Journal of Plant Physiology 27, 941-948.

Paynter, B, Hills, A, Gupta, S, Collins, S, Dhammu, H, Malik, R, Trainor, G (2014) '2015 barley variety sowing guide for Western Australia.' (Department of Agriculture and Food, Government of Western Australia: Perth, Western Australia)

Poustini, K, Siosemardeh, A (2004) Ion distribution in wheat cultivars in response to salinity stress. Field Crops Research 85, 125-133.

Rahnama, A, Poustini, K, Tavakkol-Afshari, R, Ahmadi, A, Alizadeh, H (2011) Growth properties and ion distribution in different tissues of bread wheat genotypes (Triticum aestivum L.) differing in salt tolerance. Journal of Agronomy and Crop Science 197, 21 $-30$.

Rajendran, K, Tester, M, Roy, SJ (2009) Quantifying the three main components of salinity tolerance in cereals. Plant Cell \& Environment 32, 237-249.

Rengasamy, P, Marchuk, A (2011) Cation ratio of soil structural stability (CROSS). Soil Research 49, 280-285.

Roy, SJ, Negrão, S, Tester, M (2014) Salt resistant crop plants. Current Opinion in Biotechnology 26, 115-124.

Schilling, RK, Marschner, P, Shavrukov, Y, Berger, B, Tester, M, Roy, SJ, Plett, DC (2014) Expression of the Arabidopsis vacuolar $\mathrm{H}^{+}$-pyrophosphatase gene $(A V P 1)$ improves the 
shoot biomass of transgenic barley and increases grain yield in a saline field. Plant Biotechnology Journal 12, 378-386.

Schmöckel, SM, Garcia, AF, Berger, B, Tester, M, Webb, AAR, Roy, SJ (2015) Different $\mathrm{NaCl}$-induced calcium signatures in the Arabidopsis thaliana ecotypes Col-0 and C24. PLOS One 10, e0117564.

Shabala, S (2013) Learning from halophytes: physiological basis and strategies to improve abiotic stress tolerance in crops. Annals of Botany 112, 1209-1221.

Shavrukov, Y, Gupta, N, Miyazaki, J, Baho, M, Chalmers, K, Tester, M, Langridge, P, Collins, N (2010a) HvNax3 - a locus controlling shoot sodium exclusion derived from wild barley (Hordeum vulgare ssp. spontaneum). Functional \& Integrative Genomics 10, 277-291.

Shavrukov, Y, Langridge, P, Tester, M, Nevo, E (2010b) Wide genetic diversity of salinity tolerance, sodium exclusion and growth in wild emmer wheat, Triticum dicoccoides. Breeding Science 60, 426-435.

Shipley, B, Hunt, R (1996) Regression Smoothers for Estimating Parameters of Growth Analyses. Annals of Botany 78, 569-576.

Sirault, X, James, R, Furbank, R (2009) A new screening method for osmotic component of salinity tolerance in cereals using infrared thermography. Functional Plant Biology 36, 970 - 977.

Sutton, T, Baumann, U, Hayes, J, Collins, NC, Shi, B-J, Schnurbusch, T, Hay, A, Mayo, G, Pallotta, M, Tester, M, Langridge, P (2007) Boron-Toxicity Tolerance in Barley Arising from Efflux Transporter Amplification. Science 318, 1446-1449.

Tajbakhsh, M, Zhou, MX, Chen, ZH, Mendham, NJ (2006) Physiological and cytological response of salt-tolerant and non-tolerant barley to salinity during germination and early growth. Australian Journal of Experimental Agriculture 46, 555-562.

Teakle, NL, Tyerman, SD (2010) Mechanisms of $\mathrm{Cl}^{-}$transport contributing to salt tolerance. Plant Cell \& Environment 33, 566-589.

Tester, M, Langridge, P (2010) Breeding technologies to increase crop production in a changing world. Science 327, 818-822.

The R Project for Satistical Computing (2014) 'R: A language and environment for statistical computing.' Available at http://www.r-project.org

Thoday-Kennedy, EL, Jacobs, AK, Roy, SJ (2015) The role of the CBL-CIPK calcium signalling network in regulating ion transport in response to abiotic stress. Plant Growth Regulation 76, 3-12.

Tilbrook, J, Roy, SJ (2014) Salinity tolerance. In 'Plant abiotic stress (2nd edition).' (Eds MA Jenks, PM Hasegawa.) pp. 134-178. (Wiley-Blackwell: New York)

Victoria, So (Ed. K Hollaway (2015) 'Victorian winter crop sumary 2015.' (Department of Economic Development, Jobs, Transport and Resources, Victorian Government:

Wheeler, R (2015) Barley variety sowing guide 2015. In 'South Australian sowing guide 2015.' pp. 16-20. (SARDI: Adelaide, South Australia)

Widodo, Patterson, JH, Newbigin, E, Tester, M, Bacic, A, Roessner, U (2009) Metabolic responses to salt stress of barley (Hordeum vulgare L.) cultivars, Sahara and Clipper, which differ in salinity tolerance. Journal of Experimental Botany 60, 4089-4103.

Wyn Jones, RG, Brady, CJ, Spears, J (1979) Ionic and osmotic relations in plant cells. In 'Recent advances in the biochemistry of cereals.' (Eds DL Laidman, RG Wyn Jones.) pp. 63-103. (Academic Press: London)

Yeo, AR, Lee, S, Izard, P, Boursier, PJ, Flowers, TJ (1991) Short- and long-term effects of salinity on leaf growth in rice (Oryza sativa L.). Journal of Experimental Botany 42, 881-889. 
672 Zhu, GY, Kinet, JM, Lutts, S (2001) Characterization of rice (Oryza sativa L.) F3 populations 673 selected for salt resistance. I. Physiological behaviour during vegetative growth. Euphytica 121, 251-263. 


\section{Tables}

676 Table 1. Ranking of salt tolerance (projected shoot area, ratio of pixels in salt treated:control plants) of 677 barley plants, 17 days after treatment with $250 \mathrm{mM} \mathrm{NaCl}$, shown in the context of the other traits 678 measured: ion independent tolerance (ratio of the absolute growth rate calculated from days 0 to 5 after 679 treatment), leaf health (median green:yellow pixel ratio at day 17), leaf water content (mean at day 17), 680 leaf $\left[\mathrm{Na}^{+}\right]$and $\left[\mathrm{K}^{+}\right]$(mean, 17 days after salt treatment) and the $\mathrm{K}^{+} / \mathrm{Na}^{+}$ratio. Accessions WI4304 and 681 WI4330 are genotypes developed as part of the University of Adelaide Barley Breeding Program and 682 have not been rated for malting quality as they are not commercially available. (Mean, $n=5-8$ except 683 for $*$ (ion measurements of Gairdner) $\mathrm{n}=1$ ). Refer to Figure 5 for s.e.m values for $\mathrm{Na}^{+}$and $\mathrm{K}^{+}$ 684 accumulation.

\begin{tabular}{l|l|l|l|l|l|l|l|l}
\hline \hline Genotype & Grain Use & $\begin{array}{l}\text { Ion } \\
\text { independent } \\
\text { tolerance }\end{array}$ & $\begin{array}{l}\mathrm{Na}^{+} \\
\text {accumulation } \\
(\mathrm{mM})\end{array}$ & $\begin{array}{l}\mathrm{K}^{+} \\
\text {accumulation } \\
(\mathrm{mM})\end{array}$ & $\begin{array}{l}\mathrm{K}^{+} / \mathrm{Na}^{+} \\
\text {Skiff }\end{array}$ & $\begin{array}{l}\text { Leaf } \\
\text { Water } \\
\text { Content } \\
(\mathrm{g})\end{array}$ & $\begin{array}{l}\text { Leaf } \\
\text { health }\end{array}$ & $\begin{array}{l}\text { Salt } \\
\text { tolerance }\end{array}$ \\
Parent 19 & Landrace & 0.818 & 197.9 & 173.8 & 0.88 & 0.092 & 0.923 & 0.491 \\
Fathom & Feed & 0.918 & 213.2 & 164.1 & 0.77 & 0.234 & 0.944 & 0.477 \\
Sahara 3771 & Landrace & 0.794 & 193.0 & 171.5 & 0.89 & 0.229 & 0.979 & 0.461 \\
CPI 71284-48 & Spontaneum & 0.824 & 121.7 & 199.3 & 1.64 & 0.390 & 0.979 & 0.426 \\
Schooner & Malting & 0.746 & 31.9 & 234.3 & 2.55 & 0.449 & 0.984 & 0.418 \\
Mundah & Feed & 0.700 & 168.3 & 199.7 & 0.63 & 0.061 & 0.944 & 0.381 \\
CM72 & Feed & 0.732 & 254.1 & 182.6 & 1.08 & 0.258 & 0.935 & 0.322 \\
Fleet & Feed & 0.682 & 282.3 & 182.8 & 0.53 & 0.227 & 0.906 & 0.311 \\
Barque 73 & Feed & 0.723 & 302.0 & 171.9 & 0.65 & 0.128 & 0.881 & 0.278 \\
Flagship & Malting & 0.567 & 484.2 & 278.7 & 0.57 & 0.272 & 0.928 & 0.269 \\
Keel & Feed & 0.741 & 728.4 & 478.0 & 0.66 & 0.088 & 0.809 & 0.269 \\
Baudin & Malting & 0.635 & 612.7 & 298.3 & 0.49 & 0.063 & 0.715 & 0.258 \\
YU6472 & Feed & 0.676 & 757.9 & 220.3 & 0.29 & 0.205 & 0.728 & 0.227 \\
Vlamingh & Malting & 0.645 & 737.5 & 290.4 & 0.39 & 0.100 & 0.635 & 0.223 \\
Hindmarsh & Feed & 0.611 & 925.9 & 401.7 & 0.43 & 0.015 & 0.641 & 0.220 \\
Sloop SA & Malting & 0.508 & 738.0 & 329.7 & 0.45 & 0.050 & 0.605 & 0.187 \\
Commander & Malting & 0.576 & 879.4 & 300.0 & 0.34 & 0.080 & 0.602 & 0.142 \\
WI4304 & Undetermined & 0.538 & 912.8 & 393.6 & 0.43 & 0.066 & 0.633 & 0.142 \\
Clipper & Malting & 0.460 & 870.7 & 374.1 & 0.43 & 0.069 & 0.504 & 0.117 \\
Yarra & Feed & 0.564 & 848.2 & 187.5 & 0.22 & 0.127 & 0.579 & 0.116 \\
WI4330 & Undetermined & 0.388 & 903.7 & 320.1 & 0.35 & 0.093 & 0.681 & 0.106 \\
Navigator & Malting & 0.376 & 896.0 & 228.9 & 0.26 & 0.114 & 0.642 & 0.101 \\
Gairdner & Malting & 0.500 & $1097.6 *$ & $138.4^{*}$ & $0.13 *$ & $0.036 *$ & 0.545 & 0.085 \\
\hline 685 & & & & & & & \\
\hline
\end{tabular}


(a)

(c)
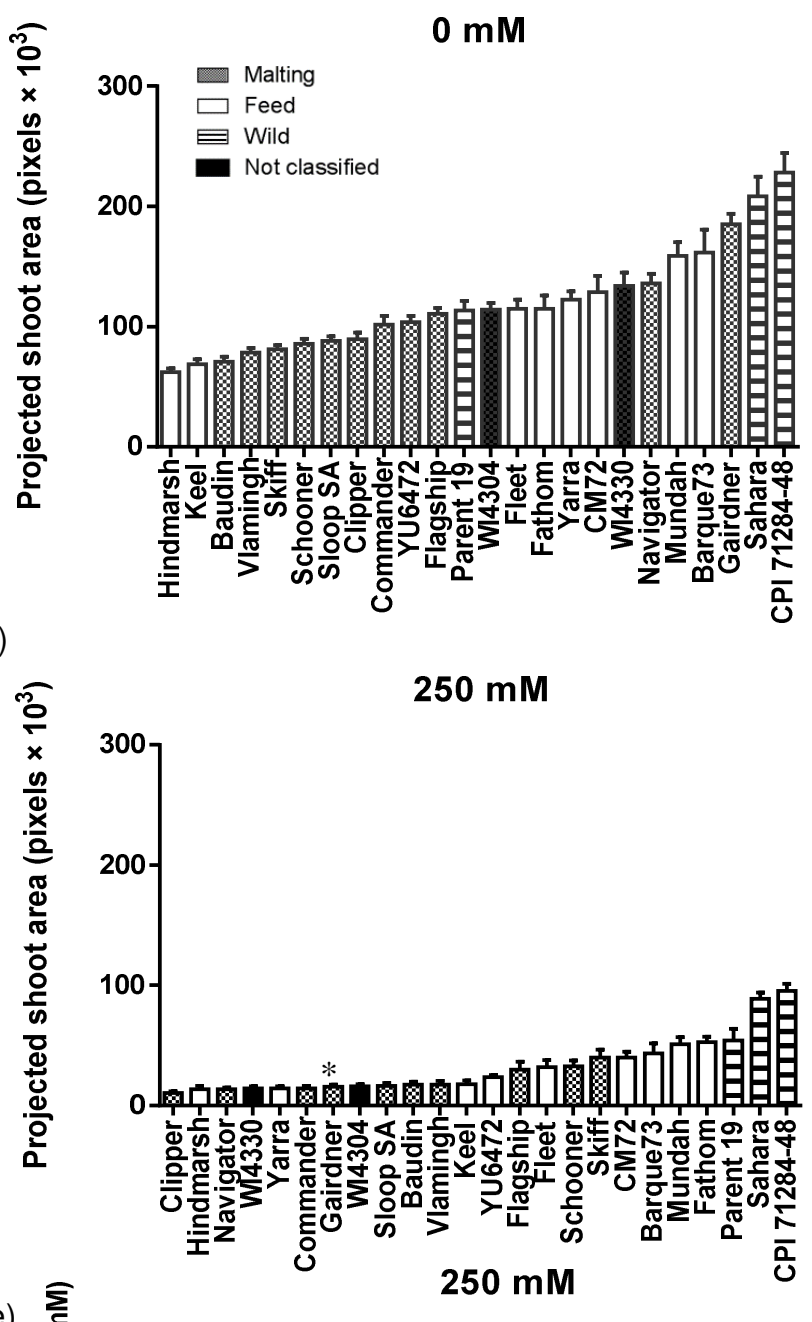

(e)

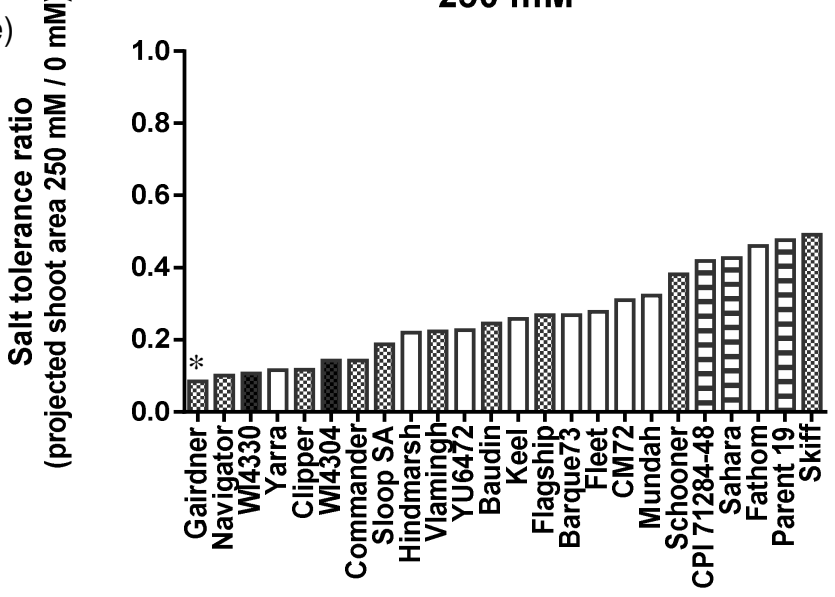

(b)

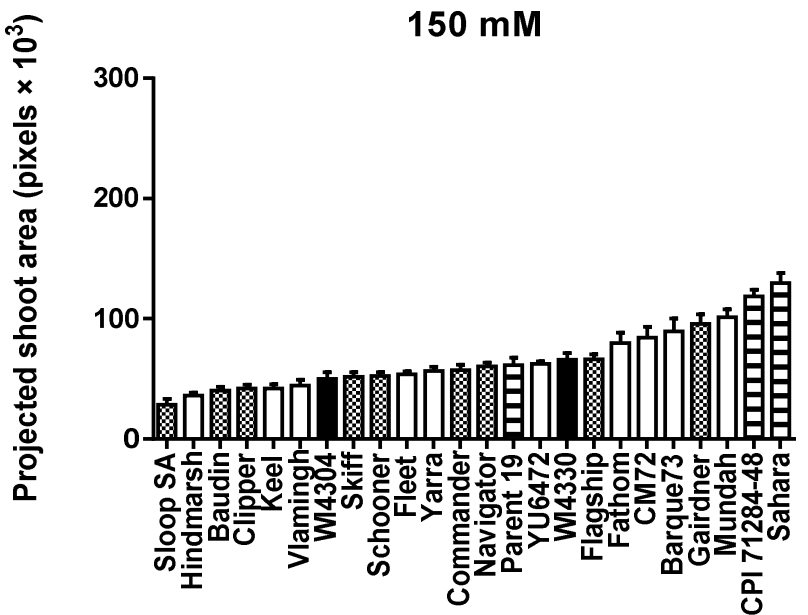

(d)

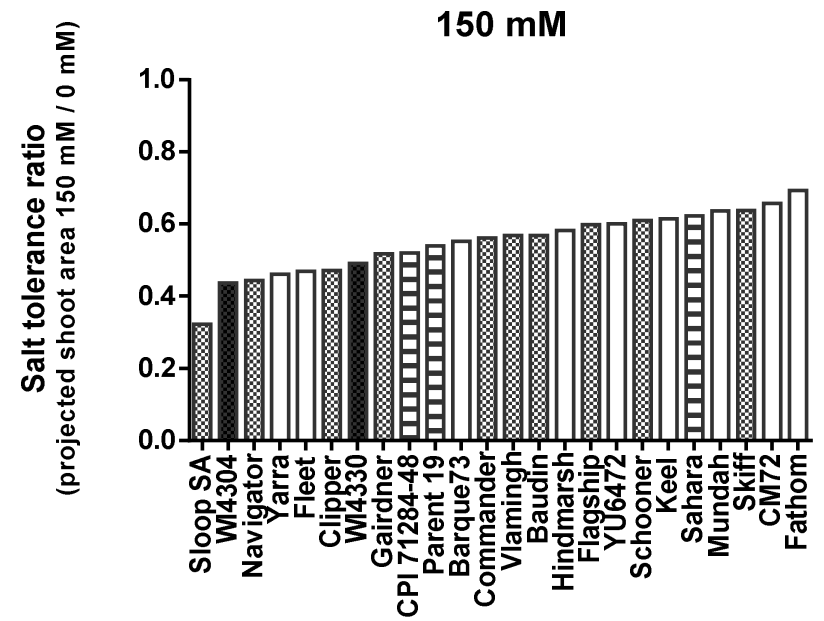

687

688

689

690
Figure 1. Projected shoot area (biomass) determined from the final imaging point, 17 days after (a) 0 $\mathrm{mM}$ (b) $150 \mathrm{mM}$ or (c) $250 \mathrm{mM} \mathrm{NaCl}$ treatments. Salinity tolerance was determined as the ratio of the projected leaf area after (d) 150 or (e) $250 \mathrm{mM} \mathrm{NaCl}$ treatment, relative to the projected shoot area of control $(0 \mathrm{mM})$ plants, at the final imaging time point. Fathom, Sahara 3771 and Skiff maintained a 
691 higher shoot area ratio at both levels of salt treatment. This contrasted with CPI 71284-48 and Parent 69219 , which maintained a high shoot area ratio at $250 \mathrm{mM} \mathrm{NaCl}$. Results are the predicted means and their 693 s.e.m. (n=5-8, * Gairdner $\mathrm{n}=1$ at $250 \mathrm{mM}$ as all other plants died). 
(a)

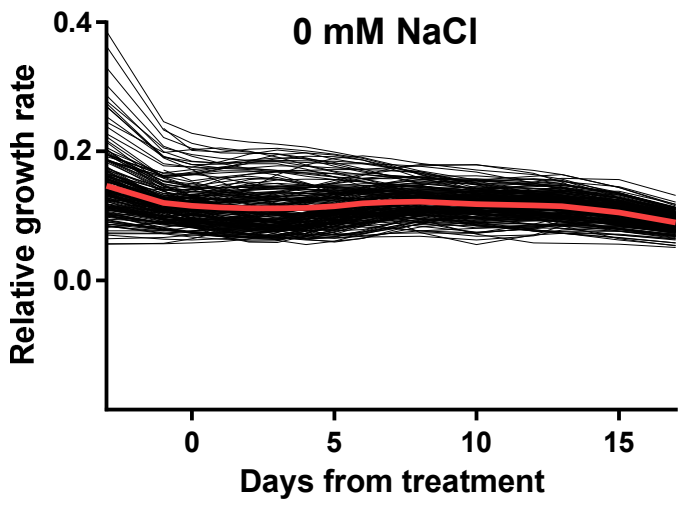

(b)

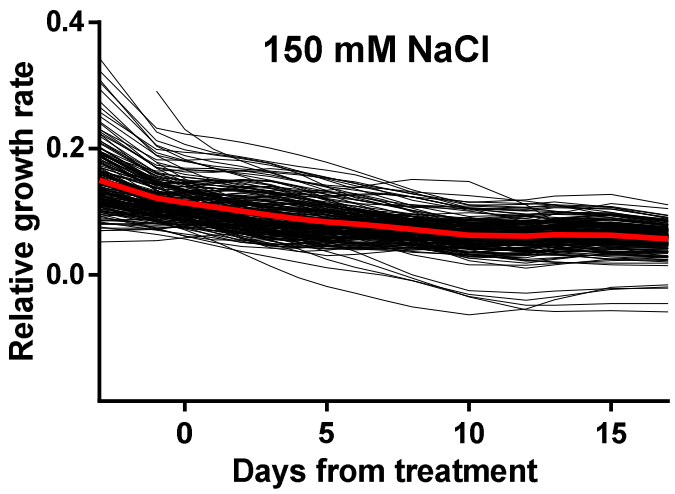

(c)

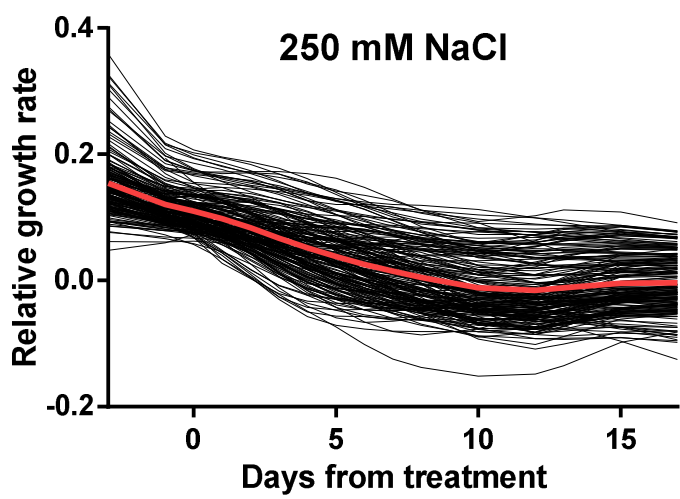

695 Figure 2. Relative growth rates of each individual barley plant before and after application of (a) 0, (b) 696150 or (c) $250 \mathrm{mM} \mathrm{NaCl}$. They are calculated from the smoothed growth curves. Salt application took 697 place at day 0 . The red line is the average relative growth rate for all plants within the experiment. 

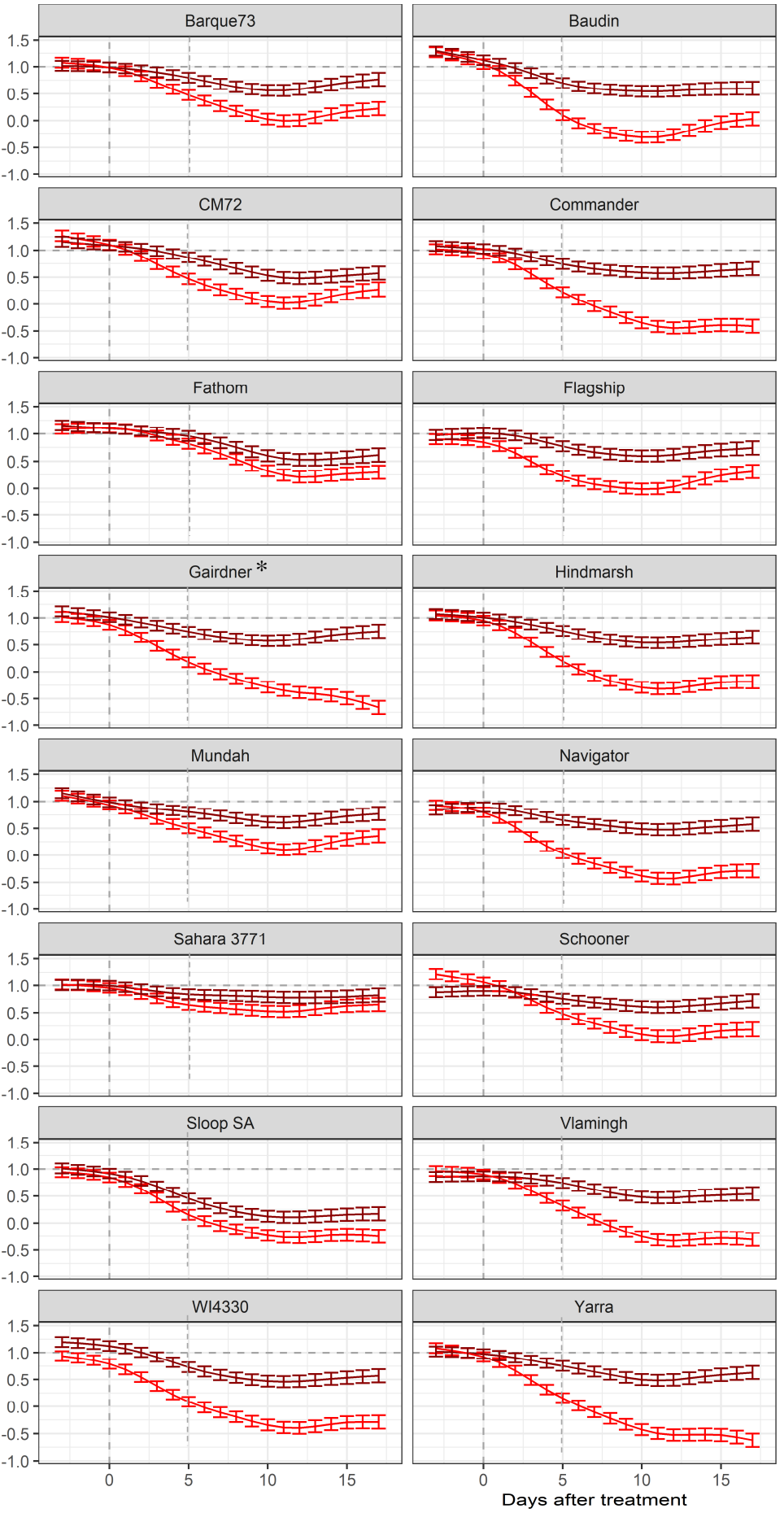
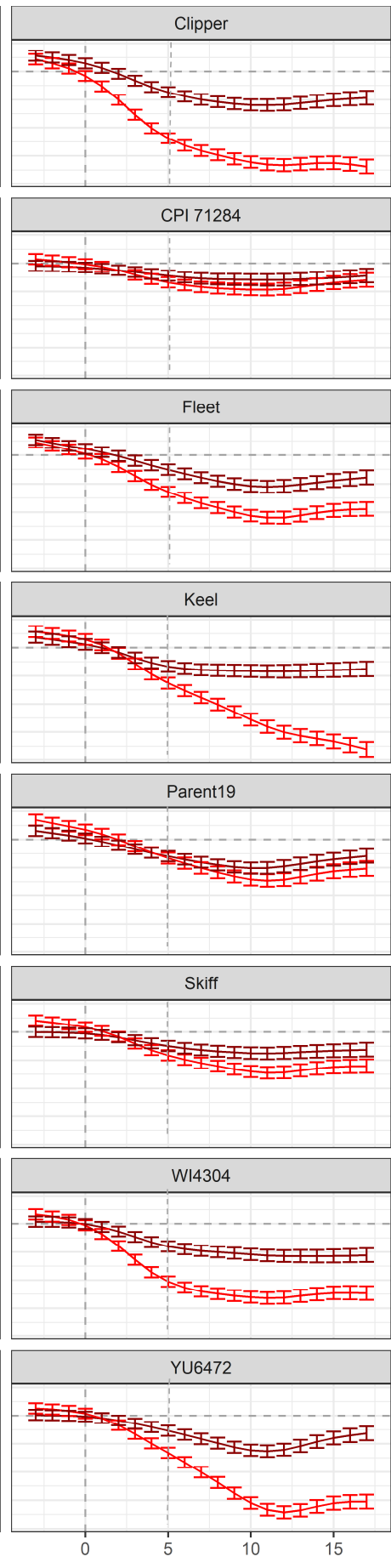

Figure 3. The ratio of the relative growth rates through time for each of the 24 barley lines grown with either $150 \mathrm{mM} \mathrm{NaCl}$ or $250 \mathrm{mM} \mathrm{NaCl}$ treatments. The ratio was determined as the relative growth rate under salt stress $\div$ relative growth rate in $0 \mathrm{mM} \mathrm{NaCl}$. The rates between the dotted vertical lines (days 0 to 5) are used to calculate the shoot ion independent tolerance. Results are the predicted means and their s.e.m. ( $\mathrm{n}=5-8,{ }^{*}$ Gairdner $\mathrm{n}=1$ at $250 \mathrm{mM}$ as all other plants died). 


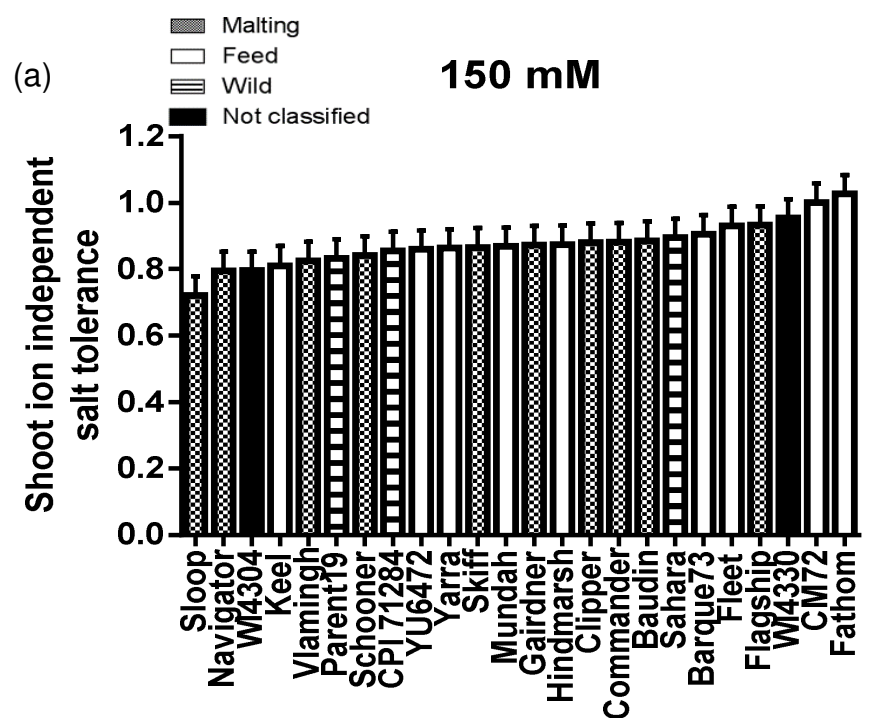

(c)

(b)

$250 \mathrm{mM}$
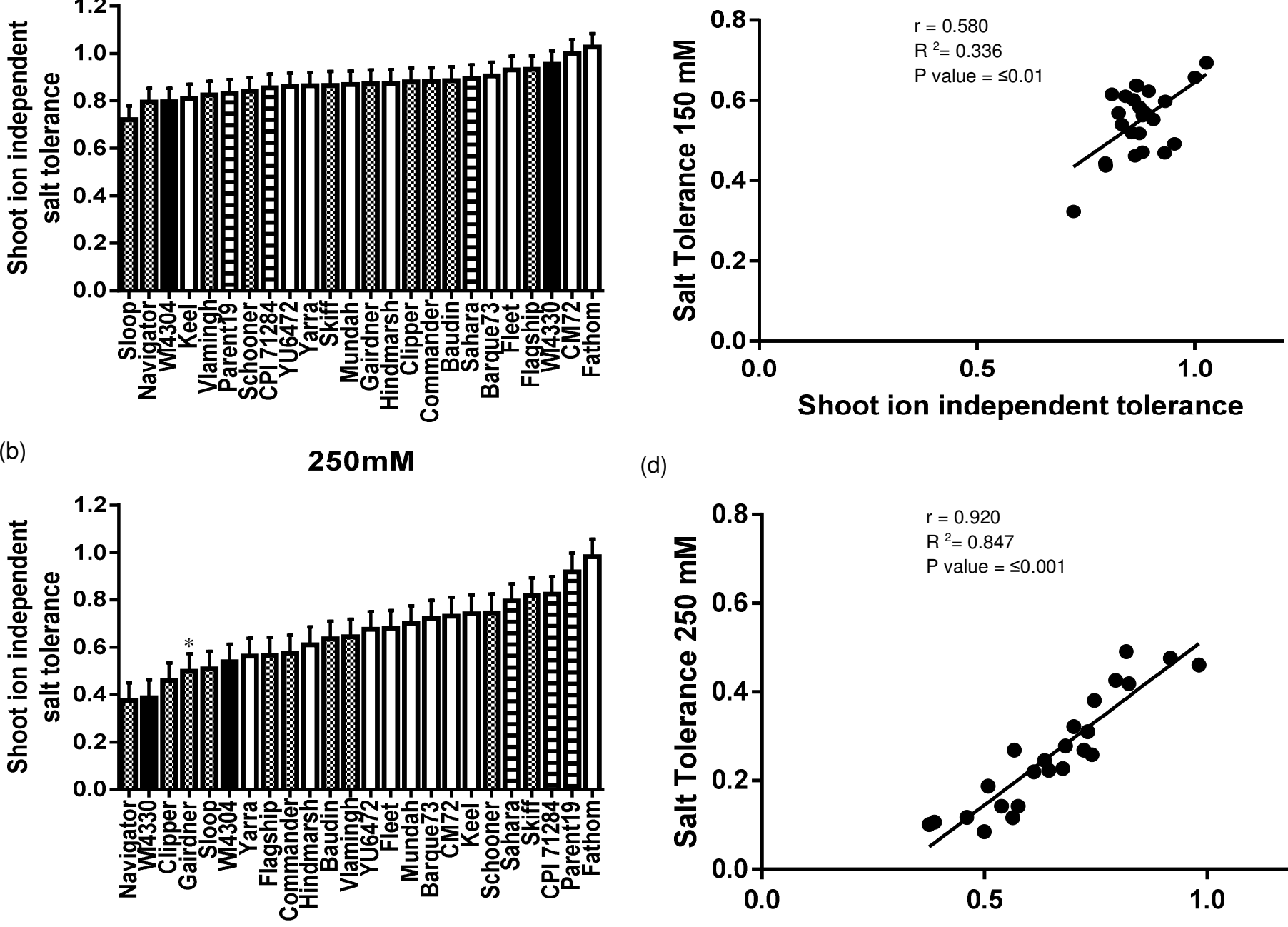

(d)

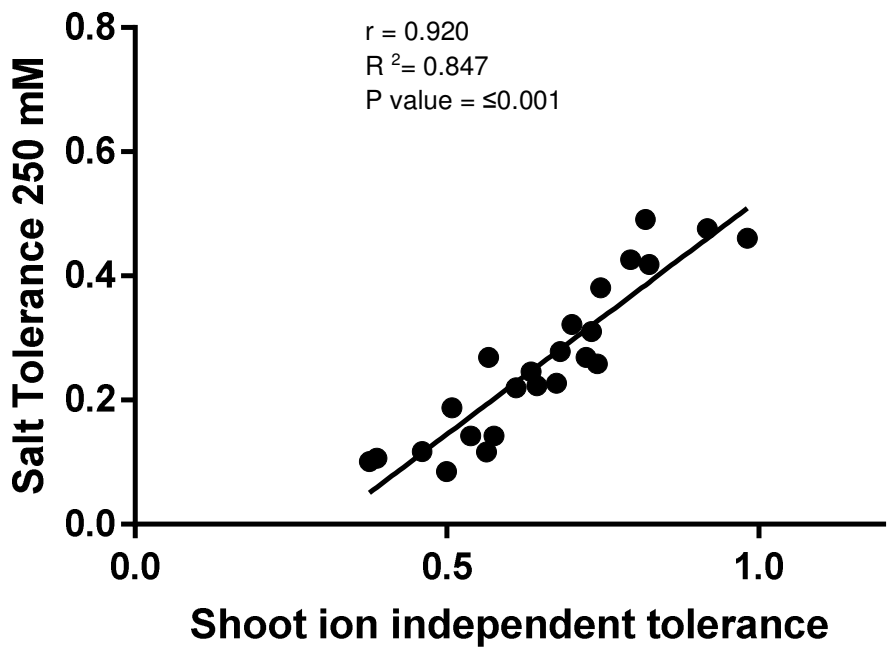

729 Figure 4. The shoot ion independent tolerance of barley seedlings over a 5 day period immediately

730 following treatment with (a) $150 \mathrm{mM}$ or (b) $250 \mathrm{mM} \mathrm{NaCl}$. A positive relationship can be observed 731 between shoot ion independent tolerance and overall plant salinity tolerance at (c) $150 \mathrm{mM}$ and (d) 250 $732 \mathrm{mM} \mathrm{NaCl}$. The shoot ion independent tolerance is expressed as a ratio of relative shoot growth rates at 733 either $150 \mathrm{mM}$ or $250 \mathrm{mM} \mathrm{NaCl} \div 0 \mathrm{mM} \mathrm{NaCl}$ over the first 5 days of salt stress. Salt tolerance was 734 determined by projected shoot area salt $\div$ projected shoot area control 17 days after treatment with 250 $735 \mathrm{mM} \mathrm{NaCl}$. Differences in tolerance was seen between lines at both treatment levels $(\mathrm{n}=5-8$, *Gairdner $736 \mathrm{n}=1$ at $250 \mathrm{mM}$ as all other plants died, results are the mean \pm s.e.m.). Pearson correlation analysis 737 results including $\mathrm{r}, \mathrm{R}^{2}$ and $\mathrm{P}$ values are shown. 

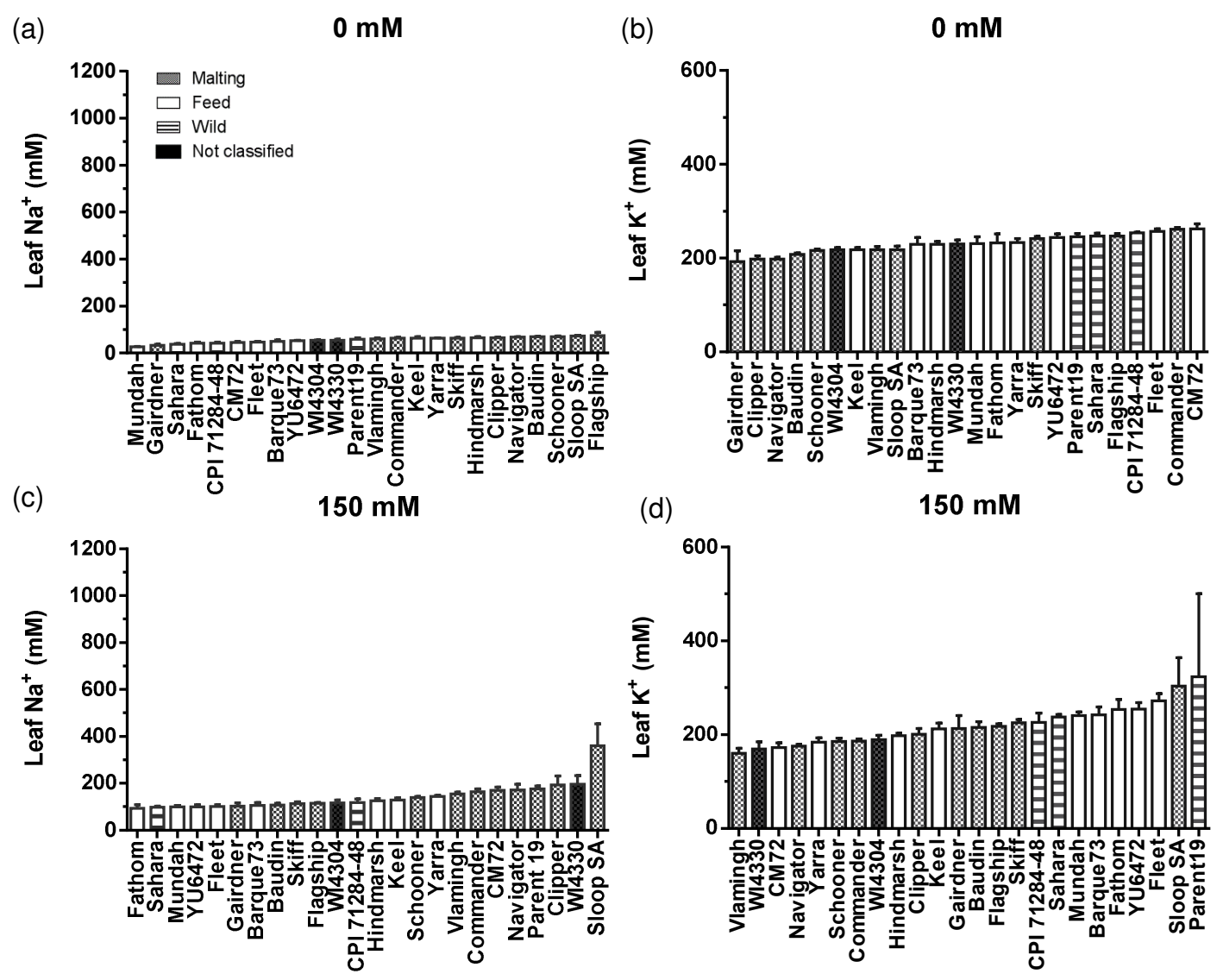

(e)

(f)
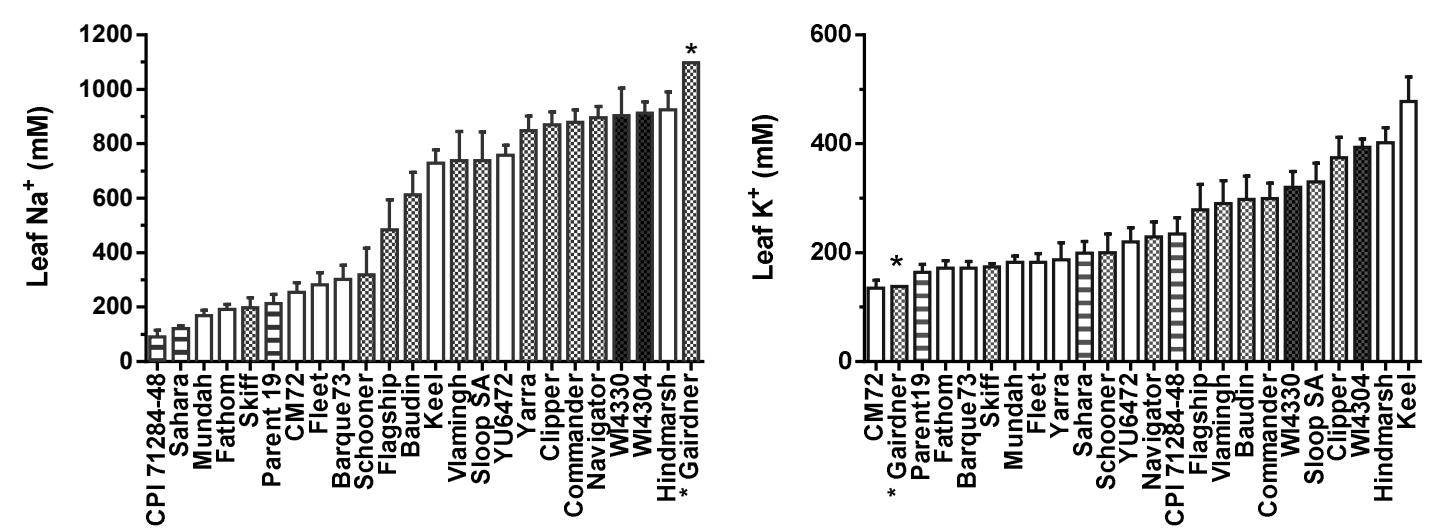

738 Figure 5. Accumulation of $\mathrm{Na}^{+}\left(\mathrm{a}, \mathrm{c}\right.$ and e) and $\mathrm{K}^{+}(\mathrm{b}, \mathrm{d}$ and $\mathrm{f})$ in leaf blades after 17 days of growth in 7390,150 or $250 \mathrm{mM} \mathrm{NaCl}\left(\mathrm{n}=5-8\right.$, s.e.m. ${ }^{*}$ Gairdner $\mathrm{n}=1$ at $250 \mathrm{mM}$ as all other plants died). 
(a)

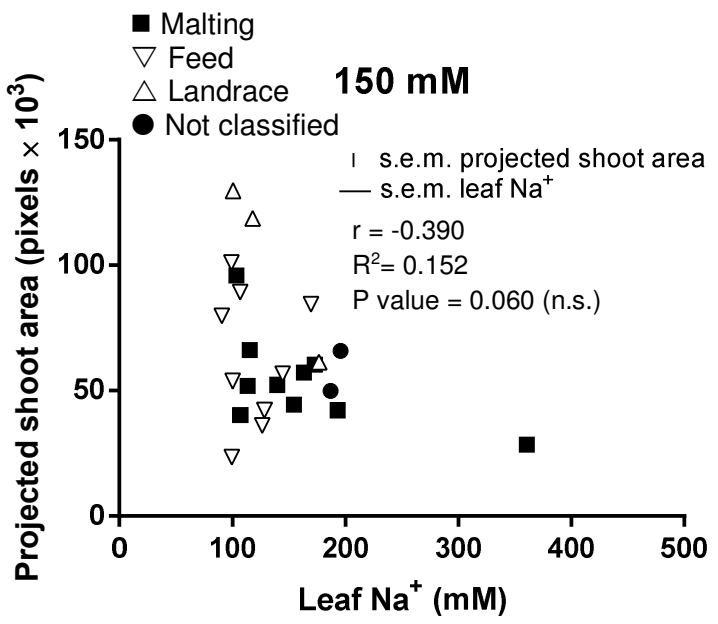

(c)

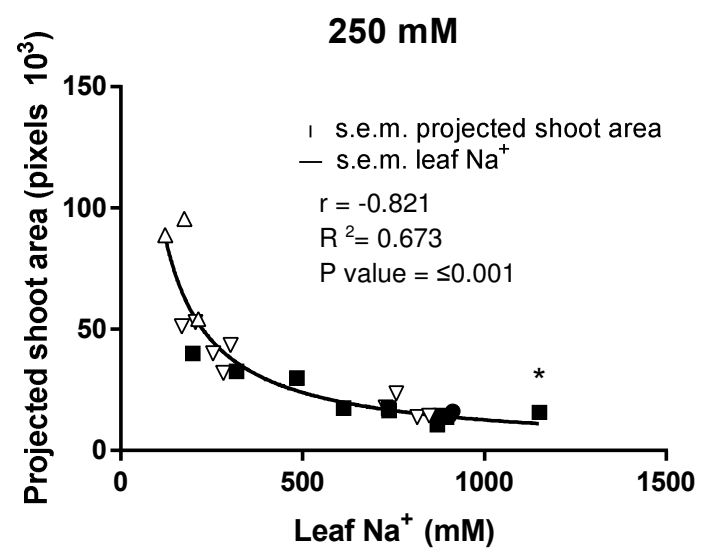

(e)

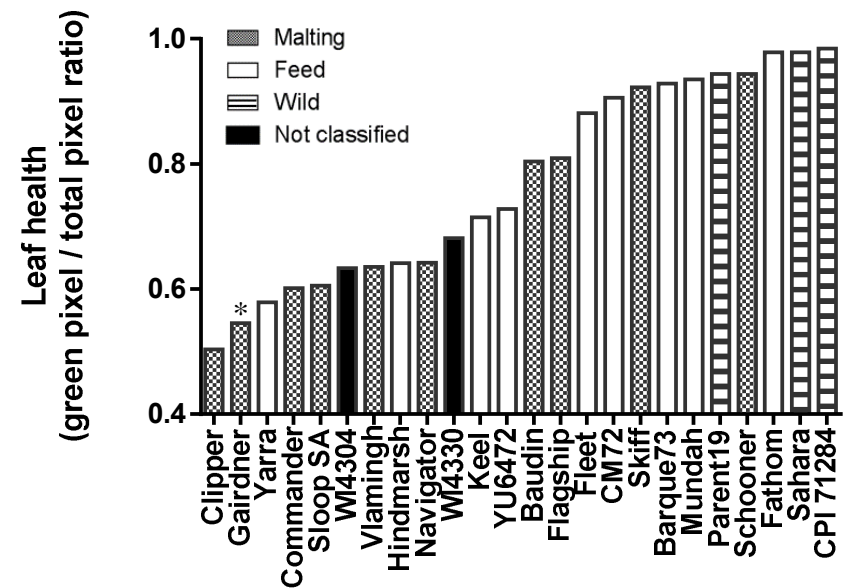

(b)

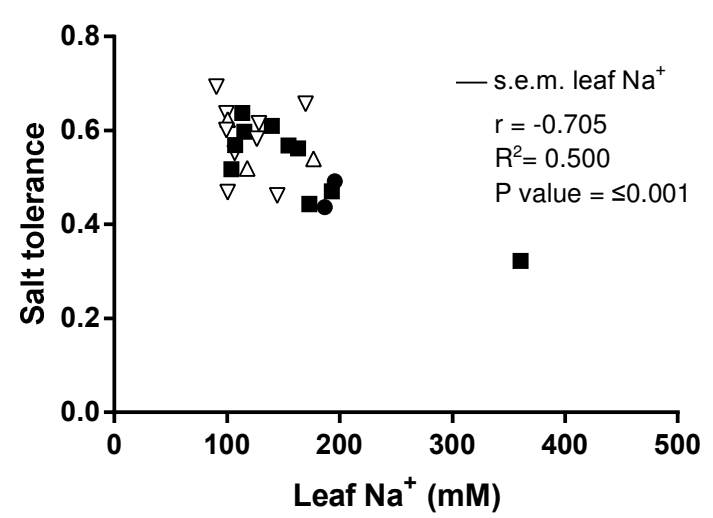

(d)

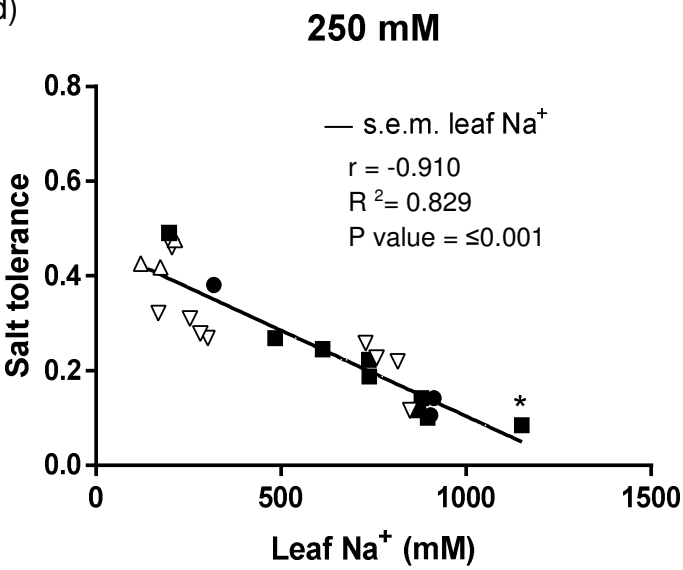

(f)

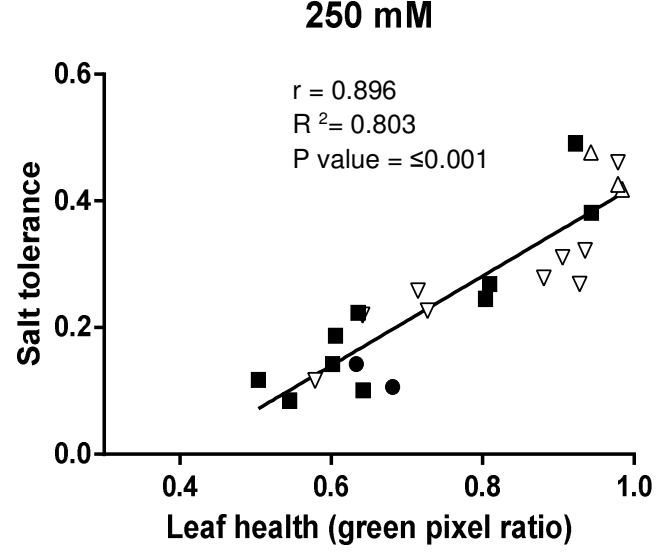

740 Figure 6. Mean leaf $\left[\mathrm{Na}^{+}\right]$vs (a) mean projected shoot area or (b) salt tolerance (projected shoot area

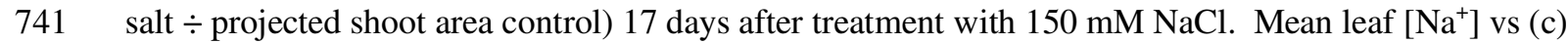
742 mean projected shoot area or (d) salt tolerance (projected shoot area salt $\div$ projected shoot area control) 74317 days after treatment with $250 \mathrm{mM} \mathrm{NaCl}$. (e) Leaf health index (number of green pixels $\div$ total plant 744 pixels) for all 24 lines after 17 days at $250 \mathrm{mM} \mathrm{NaCl}$. (f) Leaf health index (number of green pixels $\div$ 745 total plant pixels) vs salt tolerance (projected shoot area salt $\div$ projected shoot area control) 17 days 
746 after treatment with $250 \mathrm{mM} \mathrm{NaCl}$ (Mean values shown, $\mathrm{n}=5-8$, * Gairdner $\mathrm{n}=1$ at $250 \mathrm{mM}$ ). Pearson

747 correlation analysis results including $\mathrm{r}, \mathrm{R}^{2}$ and $\mathrm{P}$ values are shown. n.s. $=$ non-significant. 
748 Supplementary Files

749

750

Supplementary Table 1. Ranking of the shoot ion independent salt tolerance of barley under $150 \mathrm{mM}$

751 $\mathrm{NaCl}$ treatment, shown in the context of the other traits measured: ion independent tolerance (ratio of 752 the absolute growth rate calculated from days 0 to 5 after treatment), leaf water content (mean at 17 753 days), leaf health (median green:yellow pixel ratio at day 17), leaf $\left[\mathrm{Na}^{+}\right]$and $\left[\mathrm{K}^{+}\right]$(mean, 17 days after 754 salt treatment) and the $\mathrm{K}^{+} / \mathrm{Na}^{+}$ratio. Accessions WI4304 and WI4330 are genotypes developed as part 755 of the University of Adelaide Barley Breeding Program and have not been rated for malting quality as 756 they are not commercially available. (Mean, $n=5-8$ ). 757

\begin{tabular}{|c|c|c|c|c|c|c|c|c|}
\hline Genotype & Grain Use & $\begin{array}{l}\text { Ion } \\
\text { independent } \\
\text { tolerance }\end{array}$ & $\begin{array}{l}\mathrm{Na}^{+} \\
\text {accumulation } \\
(\mathrm{mM})\end{array}$ & $\begin{array}{l}\mathrm{K}^{+} \\
\text {accumulation } \\
(\mathrm{mM})\end{array}$ & $\mathrm{K}^{+} / \mathrm{Na}^{+}$ & $\begin{array}{l}\text { Leaf } \\
\text { water } \\
\text { content } \\
(\mathrm{g}) \\
\end{array}$ & $\begin{array}{l}\text { Leaf } \\
\text { health }\end{array}$ & $\begin{array}{l}\text { Salt } \\
\text { tolerance }\end{array}$ \\
\hline Fathom & Feed & 1.027 & 93.7 & 253.8 & 2.71 & 0.055 & 0.994 & 0.694 \\
\hline CM72 & Feed & 1.000 & 169.5 & 172.5 & 1.02 & 0.322 & 0.993 & 0.657 \\
\hline Skiff & Malting & 0.866 & 113.4 & 225.3 & 1.99 & 0.092 & 0.991 & 0.638 \\
\hline Mundah & Feed & 0.869 & 99.2 & 240.4 & 2.42 & 0.436 & 0.992 & 0.636 \\
\hline Sahara 3771 & Landrace & 0.894 & 98.9 & 237.1 & 2.40 & 0.076 & 0.990 & 0.623 \\
\hline Keel & Feed & 0.810 & 128.5 & 212.4 & 1.65 & 0.040 & 0.984 & 0.615 \\
\hline Schooner & Malting & 0.841 & 139.8 & 186.0 & 1.33 & 0.055 & 0.992 & 0.610 \\
\hline YU6472 & Feed & 0.859 & 99.7 & 255.0 & 2.56 & 0.181 & 0.992 & 0.601 \\
\hline Flagship & Malting & 0.933 & 115.4 & 217.6 & 1.88 & 0.086 & 0.991 & 0.598 \\
\hline Hindmarsh & Feed & 0.874 & 126.6 & 197.8 & 1.56 & 0.049 & 0.987 & 0.582 \\
\hline Baudin & Malting & 0.886 & 107.0 & 215.3 & 2.01 & 0.050 & 0.990 & 0.569 \\
\hline Vlamingh & Malting & 0.825 & 154.6 & 159.9 & 1.03 & 0.089 & 0.982 & 0.568 \\
\hline Commander & Malting & 0.881 & 163.2 & 186.3 & 1.14 & 0.068 & 0.988 & 0.562 \\
\hline Barque73 & Feed & 0.832 & 106.7 & 242.0 & 2.27 & 0.323 & 0.991 & 0.552 \\
\hline Parent19 & Landrace & 0.698 & 176.7 & 323.4 & 1.83 & 0.138 & 0.989 & 0.540 \\
\hline CPI 71284-48 & Spontaneum & 0.855 & 118.0 & 225.6 & 1.91 & 0.507 & 0.994 & 0.520 \\
\hline Gairdner & Malting & 0.873 & 103.8 & 213.2 & 2.05 & 0.384 & 0.989 & 0.518 \\
\hline WI4330 & Undetermined & 0.954 & 195.6 & 169.1 & 0.86 & 0.111 & 0.981 & 0.492 \\
\hline Clipper & Malting & 0.806 & 193.3 & 200.8 & 1.04 & 0.061 & 0.978 & 0.471 \\
\hline Fleet & Feed & 0.931 & 100.5 & 272.2 & 2.71 & 0.135 & 0.992 & 0.469 \\
\hline Yarra & Feed & 0.863 & 144.6 & 183.8 & 1.27 & 0.141 & 0.987 & 0.462 \\
\hline Navigator & Malting & 0.795 & 173.0 & 175.2 & 1.01 & 0.096 & 0.984 & 0.444 \\
\hline WI4304 & Undetermined & 0.796 & 116.1 & 189.0 & 1.63 & 0.019 & 0.965 & 0.439 \\
\hline Sloop SA & Malting & 0.722 & 360.7 & 303.3 & 0.84 & 0.043 & 0.850 & 0.323 \\
\hline
\end{tabular}


(a)

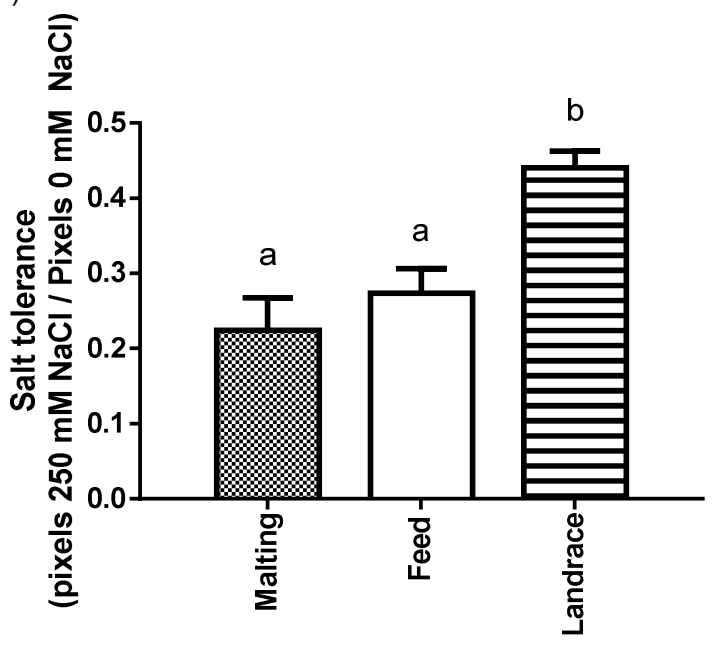

(b)

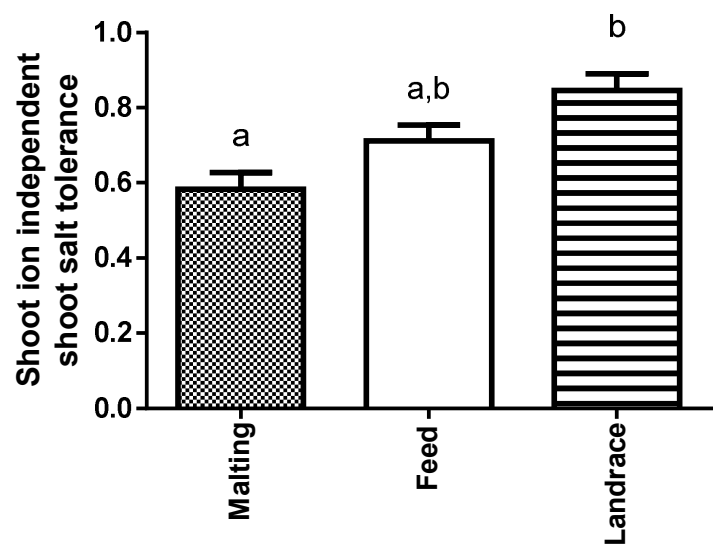

(c)

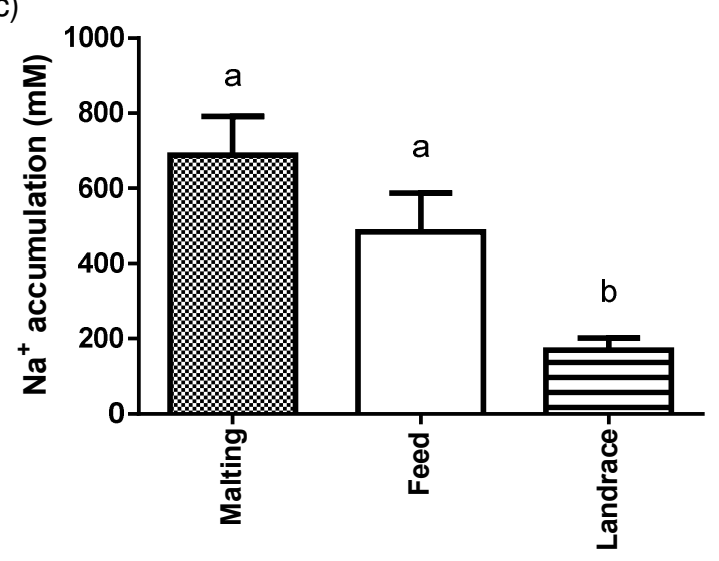

Supplementary Figure 1. Performance of barley lines when group by their malting classification for (a) salinity tolerance (size of plant in $250 \mathrm{mM} \mathrm{NaCl} \div$ size of plant in $0 \mathrm{mM} \mathrm{NaCl}$ ), (b) shoot ion independent tolerance and (c) accumulation of $\mathrm{Na}^{+}$in the leaf. Results which are significantly different $P \leq 0.05$ (One-way ANOVA) are indicated with different letters. Recent landrace derived lines were included in the landrace classification. Varieties were classified according to malting or feed characteristics. However, most malting varieties can also be used as feed barley. The landrace derived lines are significantly different to the malting and feed varieties for all three traits. 


$$
-\begin{gathered}
0 \mathrm{mM} \\
\mathrm{NaCl}
\end{gathered}-\underset{\mathrm{NaCl}}{150 \mathrm{mM}}-\underset{\mathrm{NaCl}}{250 \mathrm{mM}}
$$
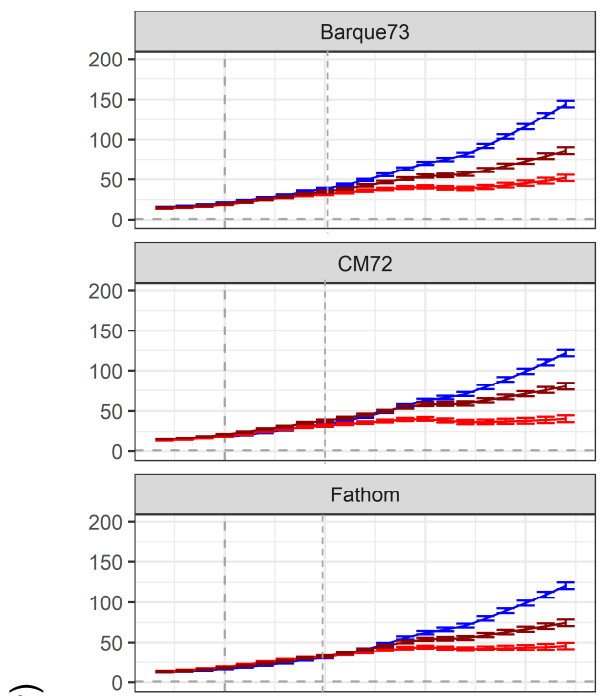

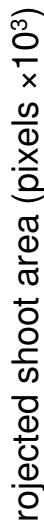

Q
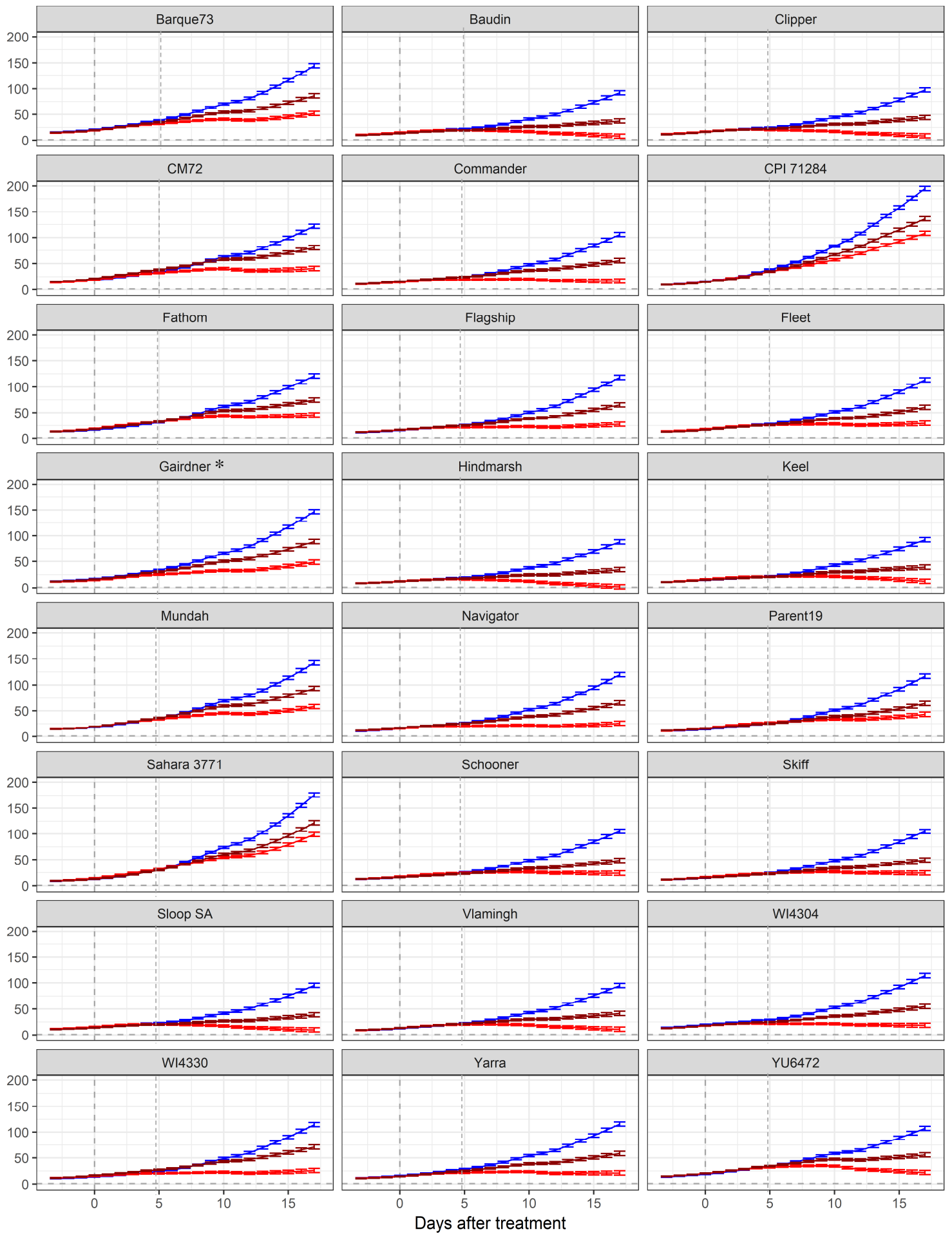

765 Supplementary Figure 2. Growth of barley over a period of 21 days with $\mathrm{NaCl}$ treatment of 0 (blue),

766150 (dark red) or 250 (light red) $\mathrm{mM}$ applied at day 0 . The period between 0 and 5 days after treatment

767 (indicated with the vertical broken lines) was used to calculate the shoot ion independent tolerance,

768 before ions were able to accumulate to high concentrations in the shoot and significantly affect shoot 
769 function. Values plotted are the mean and s.e.m. of the mean ( $\mathrm{n}=5-8 *$ Gairdner $\mathrm{n}=1$ at $250 \mathrm{mM}$ as all 770 other plants died). 


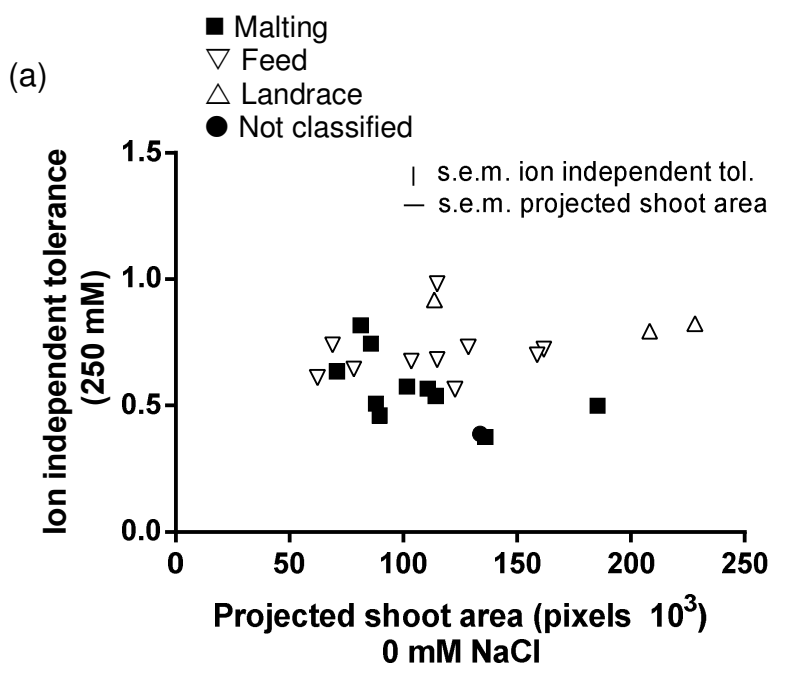

(b)

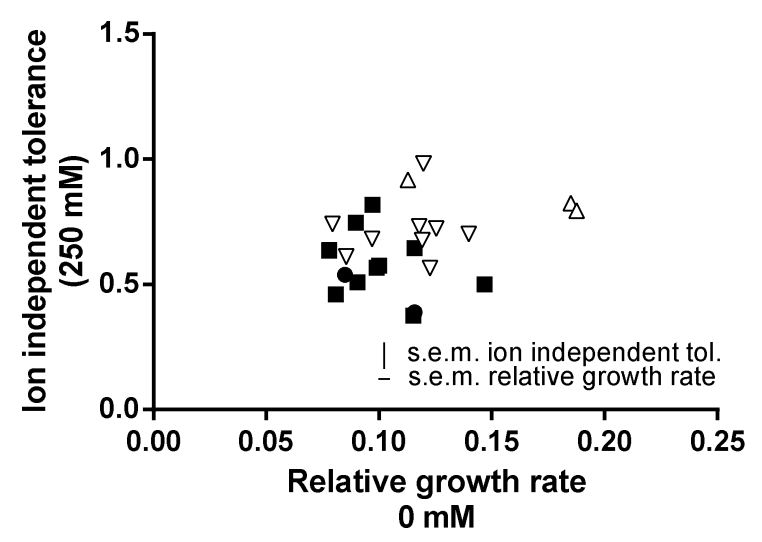

771 Supplementary Figure 3. Relationship between mean relative shoot growth rate for each cultivar at 0 $772 \mathrm{mM} \mathrm{NaCl}$ and the cultivar's ion independent tolerance at $250 \mathrm{mM} \mathrm{NaCl}$. 